\title{
Następstwa społeczno-gospodarcze kolektywizacji wsi czechosłowackiej (1948-1960) w świetle polskich źródeł dyplomatycznych i prasowych
}

\author{
Socio-Economic Consequences of Collectivization \\ the Czechoslovak Village (1948-1960) in the Light \\ of Polish Diplomatic and Press Sources
}

\section{Uwagi wstępne}

Artykuł powstał w wyniku badań dziejów społeczno-gospodarczych wsi wschodnioeuropejskiej dotyczących lat 1948-1960/196 I ${ }^{\mathrm{I}}$, a więc okresu kiedy to reżym komunistyczny w Czechosłowacji dokonał unicestwienia indywidualnej gospodarki chłopskiej. Na tle dyktatur komunistycznych Europy Wschodniej wyróżniał się on niezwykłą brutalnością i skutecznością. W artykule przedstawiono kolejne etapy kolektywizowania wsi czechosłowackiej. Ofiarami tego procesu gospodarczego były setki tysięcy chłopów czechosłowackich, o prześladowaniach których wie tylko wąskie grono badaczy.

Artykuł z polskiej perspektywy, jedynego nieskolektywizowanego państwa komunistycznego, pokazuje tragiczne dzieje sowietyzacji gospodarczej wsi czechosłowackiej oraz jej skutki dla tej społeczności. W oparciu o polskie świadectwa zaczerpnięte z Archiwum Ministerstwa Spraw Zagranicznych, prasę oraz relacje zebrane od członków prześladowanych rodzin przedstawiono „proces budowy podstaw socjalizmu na wsi” z wszyst-

I Artykuł powstał w Instytucie Ruchu Ludowego, będącym częścią Muzeum Historii Polskiego Ruchu Ludowego, w ramach tematu badawczego pt. „Sowietyzacja wsi wschodnioeuropejskiej i jej następstwa społeczno-polityczne i gospodarcze w latach 1948-1960". 
kimi jego konsekwencjami, możliwymi do pokazania w oparciu o dostępne na tym etapie badań i wykorzystane w artykule źródła. Z przyczyn obiektywnych ${ }^{2}$ nie zdołano dotrzeć do materiałów archiwalnych dotyczących kolektywizacji wsi, a wytworzonych przez aparat Komunistycznej Partii Czechosłowacji ( $\mathrm{KPCz}$ ) oraz administrację rolniczą Czechosłowacji. W artykule zanalizowano omawiany problem w oparciu o raporty polskich dyplomatów, fachowców posiadających wiedzę z zakresu ekonomiki rolnictwa.

W pierwszej części artykułu przedstawiono proces przygotowania się czechosłowackich władz do kolektywizacji wsi, a następnie zajęto się analizą przebiegu i następstwami kolektywizacji dla chłopów czechosłowackich. W dalszej kolejności w oparciu o zachowane relacje pokazano gehennę chłopów czechosłowackich, jaką przeszli oni podczas kolektywizacji. Zwrócono uwagę na wykonawców tej akcji, rekrutujących się spośród aparatu partyjnego administracji rolnej i służby bezpieczeństwa. W podsumowaniu pokazano skutki kolektywizacji rolnictwa czechosłowackiego. Należy dodać, że są one widoczne do dzisiaj.

Artykuł został napisany z polskiej perspektywy. W przyszłości zostanie przedstawiona analiza tego procesu w oparciu o źródła czechosłowackie. W artykule wykorzystano, na ile to było możliwe, źródła dokumentowe, prasowe, wytworzone przez aparat czechosłowackiej partii komunistycznej i administracji rolnej oraz zgromadzone przez polskie służby dyplomatyczne. Podczas omawiania tego problemu wykorzystano polską, czeską i słowacką, a także anglojęzyczną literaturę przedmiotu.

\section{Przygotowania do kolektywizacji wsi czechosłowackiej}

Pod koniec lat 40. XX w., dzięki sprzyjającym warunkom pogodowym i dobremu zaopatrzeniu w sprzęt rolniczy i nawozy sztuczne oraz środki ochrony roślin, rolnicy czechosłowaccy uzyskali wysokie plony. Wówczas po raz pierwszy po zakończeniu drugiej wojny światowej przekroczyli poziom przedwojennej produkcji rolniczej. Szczególnie ożywiła się hodowla trzody chlewnej, zwiększyła wydajność upraw z hektara ziemi.

W latach 40. XX w. władze czechosłowackie przejęły wiele majątków ziemskich, przekształcając je w państwowe majątki ziemskie. Miały one stanowić podstawę w procesie przekształcenia struktury rolnej Czechosłowacji z kapitalistycznej na socjalistyczną. W oparciu o te majątki

2 W 2020 roku w wyniku pandemii na świecie wprowadzono przepisy w zakresie ograniczenia przemieszczania się ludności, dostępu do instytucji publicznych, w tym bibliotek i archiwów. W tej sytuacji niemożliwe było wykorzystanie źródeł archiwalnych znajdujących się na obszarze Czech i Słowacji. 
władze państwowe wspierały powstanie dużych kombinatów warzywno-sadowniczych, farm drobiowych, farm hodowli trzody chlewnej oraz dużych tuczarni świń. W wyniku działań czechosłowackich władz państwowych w posiadaniu utworzonych, jak ostatecznie je nazwano, Państwowych Gospodarstw Rolnych (PGR) znajdowało się około 500 tys. ha ziemi, co stanowiło $8 \%$ ogólnych użytków rolnych w kraju. Wiele z tych PGR-ów powstawało w byłym Kraju Sudeckim, z którego wypędzono Niemców. W innych częściach Czechosłowacji liczba PGR-ów była znacznie mniejsza ${ }^{3}$.

Po wojnie władze państwowe opanowane przez komunistów przygotowały grunt pod wcielenie na wsi czechosłowackiej sowieckiego wzorca organizacyjnego. W gospodarstwach państwowych do zbiorów zbóż oraz przy remontach sprzętu rolniczego zaczęto zatrudniać robotników fabrycznych. W akcjach tych w 1949 r. wzięło udział około 50 tys. robotników. Władze komunistyczne zobowiązały wielkie zakłady przemysłowe, jak np. „Škoda”, do „patronatu” nad mającymi wkrótce powstać spółdzielniami produkcyjnymi.

Indywidualna wieś czechosłowacka zaopatrzona była w sprzęt rolniczy, co pozwalało władzom tworzyć zaplecze techniczne dla mających powstać spółdzielni produkcyjnych. Podczas prac polowych przeprowadzonych w 1949 r. na polach czechosłowackich wykorzystywano 26 tys. traktorów (60\% odebranych rolnikom indywidualnym), 3 I tys. snopowiązałek (w 50\% odebranych gospodarzom indywidualnym), 70 tys. żniwiarek, I70 tys. kosiarek (w około $80 \%$ odebranych chłopom). Powyższe dane wskazują, że indywidualne rolnictwo czechosłowackie było niemal całkowicie zmechanizowane. W 1949 r. sprzętem tym zebrano zboża na około 95\% areału ziemi ornej. Władze czechosłowackie, dokonując zajęcia mienia chłopskiego tanim kosztem, stworzyły bazę zaopatrzenia PGR i rolniczych spółdzielni produkcyjnych w sprzęt rolniczy. W 1949 r. władze spowodowały, że tworzone przez nie Jednolite Spółdzielnie Rolnicze lub „Spółdzielnie Uniwersalne”, czyli jednostki gospodarcze wzorowane na radzieckich kołchozach, przejęły cały park maszynowy znajdujący się w rękach dawnych spółdzielni, spółek oraz osób prywatnych. Dzięki takim decyzjom w 1949 r. spółdzielnie te stały się „czynnikiem decydującym

3 Archiwum Ministerstwa Spraw Zagranicznych (dalej: AMsz), Departament I. Wydział Czechosłowacki (dalej: DI.WCz), Czechosłowacja 242. Raporty 1949, t. 454, wiązka 49, s. 184, Sytuacja bieżąca rolnictwa Czechosłowacji 7 VI I949; M. Vomela, Kolektivizacev Československu a jejípolitické motivy, [w: Kolektivizace venkova v Československu 1948-1960 a středoevropské souvislosti, red. P. Blažek, M. Kubálek, Praha 2008, s. I19-126; Š. Rokosová, Administrativníopatření- jedna z forem perzekuce sedláků komunistickým režimem, „Securitas Imperii” 2003, č. Io, [Praha], s. I49-152; J. Burešová, Politický a institucionální rámec kolektivizace zemèdèlství v Ceskoslovensku se zaměrením na historická východiska, [w:] P. Blažek i in., Akce „K”. Vyhnáni sedláku a jejich rodin z usedlostí v padesátých letech. Studie, seznamy a dokumenty, Praha 2010, s. 40-53. 
na terenie swojej działalności” 4 . Jednolite Spółdzielnie Rolnicze, które miały powstać na wsi czechosłowackiej, zgodnie z zapisami statutu miały: a) scalać grunty dla celów zespołowej uprawy; b) mechanizować prace w rolnictwie; c) pomagać w skupie produktów rolnych i zaopatrzeniu wsi w towary przemysłowe; d) oddziaływać w celu podniesienia kultury rolnej; e) ulepszać organizację pracy w rolnictwie; f) ułatwiać pracę kobietom wiejskim; g) podnosić poziom kulturalny wsi`. Bolesław Strużek, badając ten problem przed laty, stwierdził, że zgodnie z zamysłem władz spółdzielnie rolnicze stać się miały „podstawowym instrumentem socjalistycznej przebudowy wsi"'.

Początkowo, tytułem próby, zmuszano rolników do wspólnego prowadzenia ferm drobiu, cielętników, wspólnego używania sprzętu rolniczego oraz instytucji socjalnych: żłobków i przedszkoli. Jednak już w lipcu 1949 r. wezwano rolników do wspólnego zbioru żniwnego, a następnie prac jesiennych - głównie siewów zbóż. W tym czasie chłopów nie zmuszano jeszcze do rozorywania miedz. Wkrótce, w sezonie 1950/1951, zarządzono „przejście od form prostej kooperacji do uspołecznienia środków produkcji i samej produkcji gospodarstw chłopskich"7.

Już w 1949 r. sprzętem rolniczym przejętym od bogatych chłopów zebrano zboże w około 2 tys. Jednolitych Spółdzielniach Rolniczych. W ten sposób władze państwowe opanowane przez komunistów stopniowo przełamywały opór psychiczny części ludności wiejskiej przed zmechanizowanym spółdzielczym sposobem zbierania plonów ${ }^{8}$. W tym samym celu dofinansowywały prace Państwowych Stacji Maszynowych, które dysponować miały sprzętem rolniczym i obrabiać pola indywidualnych, a potem spółdzielczych rolników. Działania te miały na celu oswojenie mieszkańców wsi z socjalistycznymi formami gospodarowania, które zamierzano szybko wprowadzić do życia gospodarczego.

\section{Kolektywizacja wsi czechosłowackiej}

Na początku lat 50. XX w. rozpoczął się gwałtowny nacisk na rolników czechosłowackich, którego celem było zmuszenie ich do masowego zrzeszania się w Jednolitych Spółdzielniach Rolniczych. Wobec opornych zaczęto prowadzić akcje represjonujące, m.in. przymusowo rozorywać istniejące

4 AMSZ, DI.WCz, Czechosłowacja 242. Raporty 1949, t. 454, wiązka 49, s. I84, Sytuacja bieżąca...

5 B. Strużek, Rolnictwo europejskich krajów socjalistycznych. Problemy spoteczno-ekonomiczne, Warszawa 1963 , s. 44.

6 Tamże, s. 44.

7 Tamże, s. 45.

8 AMSZ, DI.WCz, Czechosłowacja 242. Raporty 1949, t. 454, wiązka 49, s. I84, Sytuacja bieżąca... 
dotychczas miedze. W wyniku nacisku ekonomicznego, nękającej agitacji, szeroko prowadzonych działań terrorystyczno-represyjnych (z zamykaniem opornych rolników do więzień i obozów pracy, biciem) i powszechnych szykan powstało około 6 tys. spółdzielni, głównie niższych typów, w których ziemia i sprzęt rolniczy były nadal w dyspozycji rolników. Wkrótce jednak spółdzielnie te zlikwidowano. Rolników zmuszano do wstępowania do spółdzielni typu III, przy czym musieli oddać sprzęt rolniczy, trzodę chlewną, konie i bydło. W ten sposób pozbawiano chłopów dorobku całego ich życia. W spółdzielniach III typu ziemię obrabiano wspólnie, a zyski dzielono. W spółdzielni takiej decydującą rolę odgrywali przewodniczący nominowani przez partię komunistyczną. Ci traktowali byłych właścicieli gospodarstw jako wrogów systemu socjalistycznego w rolnictwie. Wielu z nich dyktatorsko zarządzało spółdzielniami, szykanowało ich członków - spółdzielców. W rękach byłych właścicieli gospodarstw indywidualnych pozostawiono jedynie małe działki przyzagrodowe?.

TAB. 1 Ruch założycielski czechosłowackich spółdzielni produkcyjnych typu III i IV w latach 1950-1960 (dane na koniec roku)

\begin{tabular}{|c|c|c|}
\hline Lata & $\begin{array}{c}\text { Liczba } \\
\text { spółdzielni }\end{array}$ & $\begin{array}{c}\text { Struktura spółdzielni } \\
\text { według wieku* W \% }\end{array}$ \\
\hline 1950 & 1837 & 14,0 \\
\hline 1951 & 3138 & 10,1 \\
\hline 1952 & 5848 & 21,1 \\
\hline 1953 & 6679 & 6,4 \\
\hline 1954 & 6502 & - \\
\hline 1955 & 6795 & 2,3 \\
\hline 1956 & 8016 & 9,8 \\
\hline 1957 & 11090 & 24,6 \\
\hline 1958 & 121240 & 8,4 \\
\hline 1959 & 12560 & 3,3 \\
\hline 1960 & 10816 & - \\
\hline
\end{tabular}

Uwaga: *Odsetek spółdzielni powstałych w poszczególnych latach w stosunku do stanu liczby spółdzielni na dzień 3I XII I959 roku.

Źródło: Statistická ročenka ČSSR Ig6o, Praha 1960, s. I2; Deset let JZD, Praha 1959; B. Strużek, Rolnictwo europejskich krajów socjalistycznych. Problemy spoteczno-ekonomiczne, Warszawa 1963, s. 57.

9 J. Urban, Venkov pod kolektivizační knutou. Okolnosti exemplárního „kulackého” procesu, Praha 2010 , s. 59-130, J. Burešová, Zemédèlstvi v Českých zemich a na Slovensku v podminkách „kolektivizace” 
Wkrótce chłopów czechosłowackich pozbawiono prawa własności do gospodarstw. Komuniści czechosłowaccy zamienili chłopów - z posiadaczy ziemi w wyzutych z mienia najemników będących na łasce państwa komunistycznego $^{\mathrm{IO}}$. W polowie 1949 r. całe komunistyczne kierownictwo Czechosłowacji występowało publicznie i propagowało „konieczność przejścia wsi czechosłowackiej na tory budownictwa socjalistycznego". Prezydent państwa, Klement Gottwald, zwolennik stalinowskiej wizji wsi, głosił: „nie będzie u nas socjalizmu bez przejścia wsi na tory budownictwa socjalistycznego" ${ }^{11}$.

W 1949 r., mimo nacisków propagandowych, na wsi czechosłowackiej unikano jeszcze walki z bogatymi chłopami. Wkrótce po podjęciu akcji kolektywizacji reżym komunistyczny w Czechosłowacji natrafił na opór. Ludność wiejska stanęła przeciwko prześladowaniom bardzo licznej i „zestalinizowanej" Komunistycznej Partii Czechosłowacji, władzom bezpieczeństwa, administracji rządowej i aparatowi propagandowemu państwa. Rolnicy czescy i słowaccy, którzy od dawna wyróżniali się w Europie Środkowo-Wschodniej wysokim poziomem kultury ogólnej i rolniczej, w porównaniu z innymi mieszkańcami wsi tej części kontynentu żyli we względnym dobrobycie. W jednej chwili zdegradowano ich do roli najemnych robotników rolnych wyzutych z całego zgromadzonego przez pokolenia majątku. W tej sytuacji doprowadzeni do rozpaczy spokojnie dotychczas gospodarujący chłopi przeciwstawiali się „żywiołowo komunistycznym naciskom ze Wschodu, które cofały rolnictwo do czasów pańszczyzny"

Brutalna polityka kolektywizacyjna spowodowała spadek produkcji rolnej, co odbiło się na zaopatrzeniu ludności miast w żywność. Wobec narastającego oporu rolników podjęto wobec nich działania represyjne. Pod naciskiem „sowieckich doradców” główne uderzenie skierowano wobec byłych wybitnych działaczy Czechosłowackiej Republikańskiej Partii Agrarnej. Ugrupowanie to w okresie funkcjonowania I Republiki Czechosłowackiej

1949-1960. (Poznámky k prevratuv životě a práci zemědělcư), „Česko-Slovenská Historická Ročenka” 1998, Brno, s. 197-203; I. Kvapilová, Organizační vývoj SNB v so. letech se zamérením na jeho veřejnè bezpečnostni složku, „Sborník Achivu Ministerstva Vnitra” 2004, nr 2, s. 9-73.

IO AMSz, DI.WCz, Czechosłowacja 242. Raporty 1949, t. 454, wiązka 49, s. I83, Sytuacja bieżąca...; A. Václavů, Ke sporům o zemédělské družestevnictví a kolektivizaci v Českolovensku, „Studie z Hospodářských Dějin” I998, č. IO, s. 20-2I; L. Cabada, D. Šanc, Český stranický systém ve 20. stoleti, Plzeň 2005, s. IOI-IO3.

II AMSZ, DI.WCz, Czechosłowacja 242. Raporty 1949, t. 454, wiązka 49, s. I84-185, Sytuacja bieżąca...; M. Surosz, Pepiki. Dramatyczne stulecie Czechów, Warszawa 2oı, s. 226-234; J. Matejka, Gottwald, Praha 1971, s. I86-194; M. Vomela, dz. cyt., s. I19-126; J. Burešová, Kolektivizace jako destrukčni proces v životě venkova, [w:] Kolektivizace venkova..., s. I09-116.

I2 (K.W.), Ofiary terroru w Czechach, „Jutro Polski”, II V i952, nr 8. Zob. też: P. Blažek, M. Kubálek, "Chtěl jsem mit svobodné zemédèlce ve svobodné zemi”. Sedlák a politik Stanislav Broj, [w:] Kolektivizace venkova..., s. 156-177. 
położyło ogromne zasługi pod budowę systemu demokracji parlamentarnej. Partia ta była zdecydowanie antykomunistyczna, do 1938 r. przeciwstawiająca się ścisłemu sojuszowi Czechosłowacji ze stalinowskim Związkiem Radzieckim. W 1945 r. prezydent III Republiki Czechosłowackiej Edward Beneš, chcąc się przypodobać zSRR i pamiętając swój konflikt z agrariuszami w okresie I Republiki, nie zgodził się na reaktywowanie partii. Bezpośrednio po zakończeniu wojny, w latach 1945-1948, wielu jej przywódców prześladowano, a prezesa partii - Rudolfa Berana skazano za kolaborację z Niemcami w 1939 r. na dwadzieścia lat więzienia. Należy podkreślić, że prezydent E. Beneš i jego wspólpracownicy przyczynili się do ostatecznej likwidacji tego nurtu politycznego. Partia ta niewątpliwie mogła być przeszkodą w komunizacji czechosłowackiej wsi ${ }^{\mathrm{r}}$.

Wobec oporu wsi władze komunistyczne cały impet represji skierowały przeciwko byłym działaczom Czechosłowackiej Partii Agrarnej, oskarżając ich o prowadzenie antykomunistycznego ruchu oporu. Z tych powodów na początku lat 50. XX w. wielu jej członków skazano na drakońskie kary, z wyrokami śmierci włącznie. W jednym z takich procesów, wyrokiem czechosłowackiego sądu komunistycznego z 26 IV 1952 r. na karę śmierci skazano byłego członka kierownictwa Partii Agrarnej prof. Josefa Kępkę. Temu czeskiemu uczonemu i politykowi zarzucano ,organizowanie sabotażu, zbrojnych band kułackich i szpiegowskich usług na rzecz wywiadu amerykańskiego i Zielonej Międzynarodówki" ${ }^{14}$. Należy dodać, że prof.J. Kępka organizował taki opór, broniąc bohatersko chłopów przed zniewoleniem. Polityk ten informował państwa zachodnie o zbrodniach reżymu komunistycznego popełnionych na chłopach czeskich i słowackich ${ }^{15}$. W tym samym procesie na dożywotnie więzienie skazano Antonina Chloupka - wieloletniego posła Partii Agrarnej, członka kierownictwa tej partii i prezesa Związku Zawodowego Robotników Rolnych w Czechosłowacji. Wyroki o podobnej wysokości otrzymali dr Otakar Čapek - członek władz centralnych Partii Agrarnej, rolnik prowadzący wzorowe wielohektarowe gospodarstwo oraz Franciszek Topŏl - również członek kierownictwa Partii Agrarnej oraz pracownik Banku Spółdzielczego $^{16}$. W procesach tych na wieloletnie więzienie skazano między innymi:

I3 (K.W.), Ofiary terroru...; J. Rokoský, Svobodný sedlák na svobodné pưdè. Osud agrární strany $v$ Československu po druhé svètové válce, [w:] Kolektivizace venkova..., s. 99-104.

I 4 (K.W.), Ofiary terroru...

Is V.V. Dostál, Agrárni strana. Jeji rozmach a zánik, Brno I998, s. 244-252; J. Rokoský, Jan Malypetr. Prvorepublikový premiér a Národni soud v roce 1947 (I čast), „Středni Europa” 1998, č. 82, s. 93-I08; tenże, Jan Malypetr...(II čast), „Středni Europa” 1998, č. 83, s. 9I-106.

I6 Agenti Zelené internacionály. Neprátelé naši vesnice, Praha 1952, s. I-15; J. Burešová, Zemédélská politika $v$ Československu v letech I948-1960 jako součást vývoje komunistických režimũ v Evropě, „Sborník Prací Moravských Historiků” 1996, č. 21: Studijnímateriály výzkumného projektu Československo 1945-1967, s. 87-I28. 
znanego pisarza katolickiego dr. Vácalva Renča, byłego posła z ramienia Narodowej Demokracji Wiléma Kneborta, byłego posła z ramienia Narodowej Demokracji Wlastimila Klima, oraz przywódcę młodzieży katolickiejJosefa Kostohryza. W I952 r. polski emigracyjny dziennikarz pisał:

te drakońskie wyroki na zasłużonych działaczy demokratycznych nie miały nic wspólnego z wymiarem sprawiedliwości, lecz stanowiły akt cynicznej zemsty reżymu za jego niepowodzenie w ujarzmianiu narodu przywiązanego do wolności i demokracji. Te wyroki miały być postrachem dla ludu czeskiego, który na równi z innymi ludami stawiał opór ciemnym siłom wschodniego totalizmu ${ }^{17}$.

Do spiętrzenia represji wobec czechosłowackiej ludności wiejskiej doszło w latach 1949-1959. Władze komunistyczne stosowały wszelkie możliwe represje z mordami i zabójstwami bogatszych chłopów włącznie ${ }^{18}$. W $1954 \mathrm{r}$. zmarł w więzieniu R. Beran ${ }^{19}$. Wkrótce prowadzona na szeroką skalę akcja represyjna przyniosła efekty. W czerwcu I954 r. po blisko pięciu latach kolektywizacji, już po śmierci K. Gottwalda - pod olbrzymimi portretami Marksa, Engelsa, Lenina, Stalina oraz tegoż Gottwalda ozdobionymi sztandarami Czechosłowacji i ZSRR - odbył się x Zjazd $\mathrm{KPCz}^{20}$. Stwierdzono na nim, że od 1949 r. gwałtownie wzrosła liczba kołchozów. W I950 r. wykorzystując miliardy koron (Kčs) z kasy państwowej oraz stosując przemoc, komuniści zorganizowali 3,8 tys. kołchozów. W roku 1951 było ich już 4,5 tys., w $1952-7,8$ tys., a w $1953-8,2$ tys. $^{2 x}$

I7 (K.W), Ofiary terroru... Szerzej zob.: S. Sikora, Reakcia obyvatelstva na politické procesy v Česko-Slovensku začiatkom pätdesiatych rokov, [w:] Od diktatúry k diktatúre. Slovensko v rokoch 1945-I953, red. M. Barnovský, Bratislava 1995, s. I42-151; Potlačená zprăva. Zprăva komise ÚV KSČ o politických procesech a rehabilitacich v československu (I949-1968), úvod a doslov J. Pelikán, Vien 1970, s. II-40; H. Renner, I. Samson, Dejiny Československa po roku 1945, Bratislava 1993, s. 3I-5I.

I8 S. Gdeczyński, Rozmowa z prezesem [Partii Agrarnej na Emigracji] dr Józefem Czernym pt. "Czeski ruch agrarny”, „Jutro Polski”, I3 II 1949, nr 3; J. Rokoský, Josef Černý, okupace, kolaborace (II čast), „Středni Evropa” 1997, č. 72-73, s. 152-164; V. Ruml, „Vesnický boháč”Jan Ruml (I89o-I95I), [w:] Kolektivizace venkova..., s. I83-I88; K. Kaplan, P. Paleček, Komunistický rězim a politicképrocesy $v$ Československu, Brno 2001, s. 88-95.

I9 (W.S.), Whotdzie Beranovi, „Jutro Polski” 30 VII 1954, nr I2; J. Rokoský, Rudolf Beran a jeho doba. Vzestup a pád agrárni strany, Praha 201I, s. 763-808, 8II-843; P.Žaček, Nástin rozpracováni "problematiky agrárnici". Státníbezpečností vadesátých a šedesátých letech 2o. století, [w:] Kúloze a významu agrárního hnutí v českých a československých dèjinách, Praha 2001, s. 173-186.

20 D. V. Svoboda, Rolnictwo w Czechostowacji, „Jutro Polski”, I5 VII I954, nr I3; L. Cabada, D. Šanc, dz. cyt., s. IOI-IO3; K. Vodička, L. Cabada, Politickýsystém Českérepubliky. Historie a současnost, Praha 2003, s. 58-60, 64-69, 75-79, 80-82.

2 I D. V. Svoboda, Rolnictwo...; J. Pernes, Závèrečná etapa kolektivizace zemédèlstvív Československu I957-I960, [w:] Závèrečná fáze kolektivizace zemédèlství v Československu 1957-Ig6o. Sbornik príspěvkư, red. V. Březina, J. Pernes, Brno 2009, s. II-52; J. Pešek, Obrat ve združstevňování československého zemédèlstvív letech $1957-1958$, „Československý Časopis Historický” ${ }_{19} 86$, č. 4, s. 498-499. 
ROMUALD tURKowskı Następstwa społeczno-gospodarcze kolektywizacji wsi czechosłowackiej...

TAB. 2 Rozwój spółdzielni produkcyjnych w Czechosłowacji w latach 1950-1958

\begin{tabular}{|r|r|r|r|r|r|r|r|r|r|}
\hline \multirow{2}{*}{ Lata } & \multicolumn{9}{|c|}{ Typy spółdzielni } \\
\hline 1950 & 1350 & 27,0 & 1874 & 37,0 & 1706 & 34,0 & 131 & 2,0 & 5061 \\
\hline 1951 & 1816 & 29,0 & 1356 & 23,0 & 2879 & 44,0 & 259 & 4,0 & 6310 \\
\hline 1952 & 1351 & 15,0 & 1919 & 27,0 & 5410 & 53,0 & 438 & 5,0 & 9118 \\
\hline 1953 & 974 & 12,0 & 671 & 8,0 & 6105 & 73,0 & 674 & 7,0 & 8324 \\
\hline 1954 & 676 & 9,0 & 243 & 3,0 & 5938 & 80,0 & 564 & 8,0 & 7421 \\
\hline 1955 & 810 & 10,0 & 221 & 3,0 & 6138 & 79,0 & 657 & 8,0 & 7826 \\
\hline 1956 & 521 & 6,0 & 156 & 2,1 & 7338 & 85,0 & 678 & 8,0 & 8693 \\
\hline 1957 & 115 & 1,0 & 159 & 1,0 & - & - & 11090 & 98,0 & 11364 \\
\hline 1958 & 52 & 0,4 & 77 & 0,6 & - & - & 12140 & 99,0 & 12269 \\
\hline
\end{tabular}

Źródło: Deset let JZD, Praha 1959; B. Strużek, Rolnictwo europejskich krajów socjalistycznych. Problemy spoteczno-ekonomiczne, Warszawa 1963 , s. 56.

\section{Następstwa kolektywizacji wsi czechosłowackiej}

W Czechosłowackich wydawnictwach ekonomiczno-propagandowych z czasów komunistycznych pisano, że kolektywizację przeprowadzono z myślą o bardziej racjonalnym wykorzystaniu w rolnictwie możliwości, jakie stwarza mechanizacja i zdobycze nauki. Uchwaloną w lutym i949 r. ustawę o tworzeniu rolniczych spółdzielni produkcyjnych władze państwowe uważały za wydarzenie przełomowe dla rozwoju wsi. Informując o kolektywizacji pisano, że spółdzielnie produkcyjne „powstawały początkowo w drodze łączenia istniejących już spółdzielni maszynowych i innych, działających na terenie wsi”. Pisząc o historii powstawania spółdzielni, podkreślano: „stopniowo wykrystalizowały się cztery typy spółdzielni produkcyjnych - od form najprostszych (wspólne prace polowe, przy zachowaniu własności ziemi) do tzw. typu czwartego, który dziś [w 1966 roku] dominuje na wsi

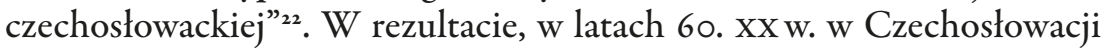
dominował typ III i IV Rolniczych Spółdzielni Produkcyjnych (Jednotne Zemědělské Družstvo - JZD), w których „obowiązywała zasada wynagrodzenia wyłącznie za pracę" ${ }^{23}$.

Na skutek działań kolektywizacyjnych chłopi czechosłowaccy stali się „socjalistycznymi robotnikami rolnymi”, pozbawionymi w większości włas-

\footnotetext{
22 V. Forst, Czechostowacja, tłum. i oprac. wersji polskiej M. Kamieniecki, Warszawa 1966, s. I54-I55.

23 Tamże, s. I55.
} 
nych gruntów. Jak zapisano w komunistycznej syntezie dziejów ekonomiczno-gospodarczych Czechosłowacji wydanej w połowie lat 60. XX w., a więc tuż po zakończeniu kolektywizacji, byli chłopi, „członkowie spółdzielni produkcyjnych mogli posiadać własną działkę przyzagrodową o wielkości pół hektara”. Spółdzielcy ci mogli na niej hodować „I krowę, I-2 prosiaki, kozy, owce i mniejsze zwierzęta gospodarskie w rozmiarach określonych przez ogólne zebranie spółdzielni” oraz niższe szczeble władz partyjno-państwowych. W Czechosłowacji były to rady narodowe szczebla gminnego lub powiatowego ${ }^{24}$. W 1961 r., a więc po zakończeniu „uspółdzielczania” wsi czechosłowackiej na v. Ogólnokrajowym Zjeździe Spółdzielni Produkcyjnych, stwierdzono, że spółdzielnie gospodarzyły już na $5 \mathrm{mln}$ hektarów użytków rolnych, stanowiących $63 \%$ areału użytków rolnych w ČSRR ${ }^{25}$.

TAB. 3 Rozwój spółdzielczości produkcyjnej w Czechosłowacji w latach 1949-1960

\begin{tabular}{|r|r|r|r|r|}
\hline Rok & Typ & $\begin{array}{c}\text { Liczba } \\
\text { spółdzielni }\end{array}$ & $\begin{array}{c}\text { Liczba } \\
\text { członków }\end{array}$ & $\begin{array}{c}\text { tącznie hektarów } \\
\text { użytków rolnych }\end{array}$ \\
\hline 1949 & II-IV & 28 & 649 & 7023 \\
\hline 1953 & II & 671 & 31852 & 113079 \\
\hline & III-IV & 6679 & 261248 & 2171908 \\
\hline 1956 & III-IV & 8016 & 395251 & 2236558 \\
\hline 1958 & Brak danych & 12140 & 851734 & 4289618 \\
\hline 1960 & Brak danych & 10816 & 994000 & 4915000 \\
\hline
\end{tabular}

Źródło: V. Forst, Czechostowacja, tłum. i oprac. wersji polskiej M. Kamieniecki, Warszawa 1966, s. 155.

Rezultat ten osiągnięto, posługując się brutalnymi metodami terroru i gwałtu oraz ucisku ekonomicznego. Publicznie mówili o tym przywódcy komunistyczni, m.in. prezydent K. Gottwald, Antonín Zápotocký i Antonín Novotný. Prowadzona przez nich polityka rolna doprowadziła do obniżenia produkcji rolnej i spadku wydajności pracy. W rezultacie władza komunistyczna „zniszczyła dobrze prosperujące [chłopskie] posiadłości rolne"26.

24 Cyt. za: tamże, s. I55. Zob. też: T. Szymczak, Organy wtadzy i administracji europejskich państw socjalistycznych, Warszawa 1970, s. 422-432.

25 V. Forst, dz. cyt., s. I55.

26 D.V. Svoboda, Rolnictwo...; V. Březina, Posledni fáze kolektivizace na středni a Severni Moravě, [w:] Závérečná fáze..., s. 56-90. W publikacji tej Březina załączył osiem dokumentów źródłowych obrazujących przebieg procesu kolektywizacji na Morawach. Zob.: V. Březina, Přlohy, [w:] Závèrečná fáze..., s. 92-128. 
Państwowe gospodarstwa rolne - mimo zabiegów władz czechosłowackich - działały w sposób fatalny. Na początku i949 r. w ich posiadaniu było około $2 \%$ ziemi, w 1952 r. miały do obrobienia grunty stanowiące 8,2\%, a dwa lata później około ıo\% areału ziemi ornej. Porównując obszar upaństwowionej ziemi na terenie Czechosłowacji do tożsamych procesów w innych państwach obozu socjalistycznego, należy stwierdzić, że w posiadaniu „pegeerów” w Rumunii znajdowało się około i \% , na Węgrzech około I2\%, a w Polsce aż I $4 \%$ całej powierzchni uprawnej ${ }^{27}$. W czechosłowackich pegeerach występowały duże trudności w ich funkcjonowaniu. Wynikały one z „nieustalonego prawa własności ziemi, ze słabego zmechanizowania, z nieustannej i wciąż zmieniającej się kadry pracowników średnich oraz częstych zmian przodowników pracy [czyli personelu pracowniczego, który uciekał z wsi do miasta], z niskiego poziomu pracowniczej i państwowej dyscypliny, a także z niedociągnięć w planowaniu i kierownictwie”.

TAB. 4 Rozwój ilościowy PGR-ów w Czechosłowacji w latach 1948-1960

\begin{tabular}{|c|c|c|c|c|c|}
\hline Rok & 1948 & 1950 & 1955 & 1959 & 1960 \\
\hline Liczba PGR & 113 & 219 & 160 & 166 & 365 \\
\hline
\end{tabular}

Źródło: V. Forst, Czechostowacja, tłum. i oprac. wersji polskiej M. Kamieniecki, Warszawa 1966, s. 158.

$\mathrm{Na}$ przełomie lat 40. i 50. władze czechosłowackie, wykorzystując duży potencjał przemysłu tego kraju, „uzbroiły rolnictwo socjalistyczne” w sprzęt traktorowo-rolniczy. W $1954 \mathrm{r}$. rozporządzano: 256 państwowymi stacjami maszynowymi, liczącymi 2277 brygad traktorowych, wyposażonych w I 8 9II traktorów (w przeliczeniu po is $\mathrm{KM}$ każdy), 20075 snopowiązałek, 919 kombajnów zbożowych i szereg innych maszyn rolniczych ${ }^{28}$. Jednak mimo zasilenia dużą liczbą nowych traktorów i dopasowanego do nich sprzętu rolniczego w Państwowych Stacjach Maszynowych (PSM) znajdowała się znaczna ilość maszyn już zużytych, zrabowanych rolnikom czechosłowackim. Wskutek złego obchodzenia się z nimi, a także z powodu braku części zamiennych, wiele z tych traktorów i maszyn rolniczych nie było użytecznych, szczególnie poniemieckich. W PSM powszechnie odczuwano brak wysoko wykwalifikowanych fachowców. Do stacji trafiali pracownicy o niskim poziomie moralnym,

27 D. V. Svoboda, Rolnictwo...; J. Poniatowski, Uwagi o ustroju rolnym, [w:] Dylematy gospodarki polskiej, red. W. Czerwiński, Londyn 1965, s. 58-67; J. Tomaszewski, dz. cyt., s. 70, 72-74, 76-77; J. Kazimour, Hospodár rký vývoj Československa, Praha I980, s. I21-I25.

28 D. V.Svoboda, Rolnictwo...; Národni hospodáŕrstvív ČSR v letech 1945-1960, Praha 1960, s. 48-49; Deset let JZD, Praha 1959, s. 26-27; W. Misiuna, dz. cyt., s. 175-186. 
dawni robotnicy - członkowie partii komunistycznej, którym legitymacja pozwoliła objąć te funkcje ${ }^{29}$.

W drugiej połowie lat 50. władze komunistyczne spowodowały, że w PSM w Rolniczych Spółdzielniach Produkcyjnych zatrudniono około 4 tys. fachowców z zakresu rolnictwa: inżynierów, agronomów oraz pracowników technicznych. Władze państwowe doprowadziły do przymusowego "przesunięcia” około 30 tys. robotników, głównie członków KPCz, do pracy w stacjach maszynowych i spółdzielniach produkcyjnych ${ }^{30}$.

Mimo wysiłków władz komunistycznych rolnictwo czechosłowackie zostało daleko w tyle za rolnictwem zachodnim. W 1952 r. na tysiąc hektarów ziemi ornej przypadało pięć traktorów. Natomiast w krajach sąsiadujących: np. Austrii - było ich 25, podobnie w Niemczech Zachodnich także 25 traktorów, a w Wielkiej Brytanii i Francji po 27 . W tym czasie w rolnictwie zachodnim postępowała mechanizacja, gwałtownie przybywało traktorów oraz sprzętu rolniczego, natomiast w Czechosłowacji obserwowano stagnację ${ }^{31}$.

W czasie rządów komunistów w Czechosłowacji doszczętnie zlikwidowano prywatną inicjatywę w przemyśle, budownictwie, transporcie, handlu i bankowości ${ }^{2}$. W I954 r. spółdzielnie produkcyjne objęły $47 \%$ wsi. W spółdzielniach tych hodowano głównie bydło. W ich rękach znalazło się $33 \%$ ziemi uprawnej. W połowie lat 50 . w $53 \%$ wsi nadal zachowały się indywidualne gospodarstwa chłopskie. Natomiast w $47 \%$ wsi podlegających kołchozom, około $30 \%$ mieszkających tam rolników odmówiła wstąpienia do spółdzielni produkcyjnej33.

29 D. V. Svoboda, Rolnictwo...; S. Cambel, Pät'desiate roky na slovenskej dedine: najt́ažšie roky kolektivizácie, Peršov 2005, s. 253-303, seznam č i; Protokolárni seznam „rodinných celkù odsouzených vesnických boháču” určených k vystěhováni v Akci „K” („Kulaci”), [w:] P. Blažek i in., Akce „K”..., s. 315-317. Karel Jech zgromadził blisko 2 tys. nazwisk mężczyzn - głów rodzin oraz podał liczbę członków tych rodzin. Badacz ten wymienił miejscowości, z których wysiedlono rodziny chłopskie oraz miejsca osadzenia. Ważną informacją zamieszczoną w publikacji są daty wysiedlenia. Jak wynika ze zgromadzonych danych, rodziny wyrzucono z dotychczasowego miejsca zamieszkania metodą bolszewicką, niezależnie od pory roku, nie licząc się z żadnymi zasadami. Rodziny chłopskie usuwano w okresie późnej jesieni I95I r., zimy 1952 r., w okresie wiosno-letnim lat 1952-1953. Rodziny traktowano bardzo brutalnie, bito, niszczono dobytek. Utraciwszy dorobek całego życia wielu rolników zmarło. Oprawcami byli szeregowi działacze komunistyczni, często robotnicy rolni, którzy podżegani przez władze bezpieczeństwa mścili się na swych dawnych chlebodawcach. Dokumentację źródłową tych wydarzeń zamieszczono w dwutomowym dziele pt. Vyhnanci. Akce „Kulak”, zločin proti lidskosti, Praha 2008-2011, zebrał Miloslav Růžička.

30 D. V. Svoboda, Rolnictwo...; J. Rychlík, Collectivization in Czechoslovakia in Comparative Perspective, 1949-1960, [w:] The Collectivization of Agriculture in Communist Eastern Europe. Comparison and Entanglements, red. C. Iordachi, A. Bauerkämper, Budapešt-New York 2014, s. 189-196.

3 I D. V. Svoboda, Rolnictwo...; J. Pernes, Snahyo prekonáni politicko-hospodárskékrize v Československu v roce 1953, Brno 2000, s. 7-11, 16-26, 48-70.

32 D. V. Svoboda, Rolnictwo...

33 Tamże; V. Březina, Kolektivizace zémédělstvív Československu v letech I955-196o, [w:] Kolektivizace venkova..., s. I28-135; K. Kaplan, Československo v letech 1945-1948, cz. I, Praha I991, s. II6; 
ROMUALD tURKowskı Następstwa społeczno-gospodarcze kolektywizacji wsi czechosłowackiej...

TAв. 5 Wyposażenie Stacji Maszynowo-Traktorowych w latach 1949-1959

\begin{tabular}{|c|r|r|r|r|r|}
\hline Rodzaj sprzętu & 1949 & 1953 & 1957 & 1958 & 1959 \\
\hline Ciągniki (przeliczeniowe) & 6129 & 15765 & 32067 & 35473 & 22080 \\
\hline Siewniki zbożowe & 670 & 5877 & 18140 & 20264 & 6749 \\
\hline Sadzarki ziemniaków & - & 4821 & 6590 & 6395 & - \\
\hline Nakładacze nawozu & - & 3 & 2671 & 4281 & - \\
\hline Snopowiązałki & 2038 & 19493 & 15094 & 17477 & 5909 \\
\hline Kombajny zbożowe & 101 & 885 & 3130 & 3752 & 3740 \\
\hline Młockarnie & 919 & 16601 & 12497 & 10107 & 2786 \\
\hline
\end{tabular}

Źródło: V. Forst, Czechostowacja, tłum. i oprac. wersji polskiej M. Kamieniecki, Warszawa 1966, s. 157.

W drugiej połowie lat 50. komunistyczne władze Czechosłowacji postanowiły przyspieszyć i zakończyć kolektywizację wsi. Najpierw w latach 1953-I955 zwolniono tempo kolektywizacji celem, jak pisał B. Strużek, „organizacyjno-gospodarczego ich [spółdzielni] wzmocnienia”. Aby to osiągnąć, władze podjęły następujące działania: „a) zwiększono inwestycje i kredyty rolnicze, b) rozszerzono pomoc ze strony Państwowych Ośrodków Maszynowych, c) znacznie zwiększono dostawy nawozów mineralnych, d) obniżono normy dostaw obowiązkowych, e) podniesiono ceny na produkty rolne, f) polepszono zaopatrzenie w artykuły przemysłowe"34.

Władze czechosłowackie zmniejszyły represje wobec dotychczas brutalnie prześladowanych bogatszych rolników. Od 1957 r. „zezwolono” na ich przyjmowanie do spółdzielni. Wielu rolnikom średniorolnym oddano skonfiskowane domy i zezwolono na posiadanie działek przyzagrodowych. W wyniku tych działań doprowadzono do tego, że na przełomie lat 1959 i 1960 w Czechosłowacji działało ıo,8 tys. spółdzielni produkcyjnych. Zrzeszały one 715 tys. gospodarstw rolnych gospodarujących na około $5 \mathrm{mln}$ ha ziemi. Wynikiem akcji uspółdzielczania wsi przez komunistów czechosłowackich było objęcie: „[...] społecznymi formami gospodarowania $51 \%$ ogólnej liczby gospodarstw chłopskich, $87 \%$ powierzchni użytków rolnych oraz ponad $90 \%$ powierzchni gruntów ornych będących we władaniu chłopów"35.

Po przechwyceniu niemal całości gruntów rolnych doprowadzono do scalenia drobnych spółdzielni produkcyjnych na wzór sowiecki w duże

tenże, Československo v letech I948-1953, cz. 2: Zakladatelské obdobi komunistického režimu,

Praha 1992, s. 10-II, 27-28.

34 B. Strużek, dz. cyt., s. 58.

35 Tamże, s. 59. 
obszarowo - jak na warunki czechosłowackie - gospodarstwa rolne. W I960 r. z 10,8 tys. spółdzielni utworzono 1323 kombinaty rolne. W ten sposób zatarto stare granice wsi. W sposób bezpowrotny zlikwidowano szachownicę pól. W ten sposób na czechosłowackiej wsi zaczęly dominować wielkoobszarowe gospodarstwa spółdzielcze i państwowe ${ }^{36}$.

\section{Funkcjonowanie czechosłowackich wsi spółdzielczych}

W wyniku zmian w rolnictwie czechosłowackim w połowie lat $50 . \mathrm{XX}$ w. wyraźnie obniżyła się produkcja rolnicza. Nawet na terenach mających dobre warunki do hodowli stan bydła mlecznego był niski. W latach 1954-1957, a więc w okresie ponownej gwałtownej kolektywizacji wsi, stan pogłowia krów zmniejszył się o około 7\%. W gospodarstwach spółdzielczych przypadało wówczas około dwudziestu krów na roo ha ziemi. Jak pisał polski obserwator procesu uspółdzielczania wsi czechosłowackiej, nie spowodował on zwiększenia produkcji zwierzęcej. Wobec niedbałej gospodarki paszowej brak było karmy dla krów. Spółdzielcze zagospodarowanie łąk pozostawiało wiele do życzenia ${ }^{37}$. Dążąc do rozwoju hodowli bydła, państwo czechosłowackie wyasygnowało ogromne środki na budowę infrastruktury spółdzielczej. Dla przykładu, w roku 1952 oddano do użytku obory dla 270 tys. sztuk bydła. Jednak wobec spadku pogłowia wiele z nich stało pustych. Cztery lata później, w 1956 r., wobec zmniejszenia pogłowia krów, wybudowano obory tylko dla Io6 tys. sztuk.

W połowie lat 50. Xxw. zaczęły rosnąć koszty uzbrajania kolejnych spółdzielni w infrastrukturę przemysłową. Jeśli w roku 1953 nakłady na przygotowanie jednego miejsca dla krowy wynosity około 5 tys. Kčs, to w roku 1956 wzrosły niemal dwukrotnie, do ponad 9 tys. Kčs. Pod koniec lat 50. gwałtownie wzrosło zużycie materiałów budowlanych niezbędnych do budowy obór. Powodem tej sytuacji była nieustannie trwająca rozbudowa spółdzielni. W konsekwencji nastąpił wzrost cen materiałów budowlanych. Na przykład cegła zdrożała o $136 \%$, cement $-243 \%$, a stal $-523 \%$. Tak znaczący wzrost cen uniemożliwiał dalszą rozbudowę spółdzielczości produkcyjnej ${ }^{38}$.

36 Tamże, s. 60-6I.

37 AMSZ, DI.WCz, Czechosłowacja 252.t. 450, wiązka 49, s. 138, Notatka z III Ogólnopaństwowego Zjazdu Jednolitych Spółdzielni Produkcyjnych (JZD) z 27 III 1957. Zob. też: W. Misiuna, dz. cyt., s. $175-186$.

38 AMSZ, DI.WCz, Czechosłowacja 252, t. 450, wiązka 49, s. 139, Notatka z III Ogólnopaństwowego Zjazdu...; A. Chyba i in., Vývoj Československé ekonomiky a hospodárská politika KSČ. Studijni materiály, Praha 1971, s. 135-150; Historia gospodarcza Czechostowacji XX wieku, pod red. V. Průchy, Warszawa 1979, s. 294-304. 
Spadek produkcji rolnej w czechosłowackich spółdzielniach spowodowany był też „wysokim wiekiem spółdzielców” ${ }^{39}$. Młodzież wiejska, nie chcąc być słabo opłacanymi robotnikami rolnymi, migrowała do miast. Po ukończeniu szkół rolniczych, wielu młodych ludzi, mężczyzn i kobiet, zamiast w produkcji rolniczej znajdowało zatrudnienie w biurach. Natomiast na wsi zostawali młodzi spółdzielcy o niedostatecznym wykształceniu i przygotowaniu do pracy ${ }^{40}$.

W I957 r. władze partyjno-państwowe Czechosłowacji wprowadziły w życie bardziej liberalny, niż obowiązujący od 1949 r., statut Jednolitej Rolniczej Spółdzielni Produkcyjnej. W wyniku zmian ten wzorcowy dokument stał się odtąd podstawą do opracowania statutu własnego dla każdej oddzielnej spółdzielni produkcyjnej. W latach 1949-1956 statut wzorcowy stanowił dla członków spółdzielni „podstawowe prawo”, co wykluczało jakiekolwiek od niego odstępstwo. W statucie z 1957 r. zmniejszono uprawnienia dotychczas wszechwładnych rad narodowych. Pozbawiono je możliwości wykluczania członków Jednolitych Rolniczych Spółdzielni Produkcyjnych. Dotychczas bowiem karano spółdzielców: „za mało wydajna praca, przeciwstawianie się uspółdzielczaniu wsi, niewywiązywanie się z obowiązku pracy, odmawianie płacenia podatków z działki przyzagrodowej itp.” Rady pozbawiono też uprawnień do udziału w „ustaleniu wartości wniesionego przez członka spółdzielni inwentarza żywego i sprzętu rolniczego". Prawo to uzyskiwał na powrót Zarząd Spółdzielni. Zgodnie z nowym statutem, począwszy od 1957 r., przyjmowano do Rolniczych Spółdzielni Produkcyjnych byłych bogatszych chłopów zwanych „kułakami” wówczas już spauperyzowanych, sponiewieranych przez przedstawicieli reżymu komunistycznego. Jednak mimo pewnego złagodzenia represji nadal, przez pięć lat, nie mogli oni pełnić w spółdzielniach funkcji kierowniczych. Zgodnie z nowym statutem spółdzielczym zarząd danej spółdzielni zyskał prawo i obowiązek wypłacania odszkodowania za wniesiony inwentarz żywy. Każdy rolnik-spółdzielca, który oddał do spółdzielni inwentarz żywy, miał otrzymać odszkodowanie finansowe. Dotychczas za inwentarz żywy nie płacono, tłumacząc, że w wielu spółdzielniach nie było dochodów, a więc odpowiednich na ten cel środków. Wobec braku siły roboczej w statucie spółdzielczym zapisano, że młodzież mogła już od piętnastego roku życia pracować w spółdzielniach i być jej członkiem. Zgodnie z decyzją władz w statucie nakazywano „oddać do wspólnego gospodarstwa ziemię, którą w jakikolwiek sposób nabył członek Jednolitej Rolniczej Spółdzielni

39 A MSZ, DI.WCz, Czechosłowacja 252, t. 450, wiązka 49, s. I 43, Notatka z III Ogólnopaństwowego $\mathrm{Zjazdu...}$

40 Tamże; J. Tomaszewski, dz. cyt., s. $72-73$. 
Produkcyjnej”. W I957 r. zniesiono zakaz dotyczący liczby posiadanych owiec i kóz będących własnością spółdzielcy. W latach 1949-1956 własnością spółdzielcy mogły być jedynie trzy kozy i pięć owiec ${ }^{41}$. Począwszy od I957 r. zezwolono spółdzielcom na hodowlę w przyzagrodowym gospodarstwie dowolnej liczby kóz i owiec.

TAB. 6 Produkcja rolnicza w Czechosłowacji w latach $1948-1958^{*}$ (w procentach)

\begin{tabular}{|l|l|r|r|r|r|}
\hline \multicolumn{2}{|c|}{ Rodzaj produkcji } & 1948 & 1952 & 1956 & 1958 \\
\hline \multicolumn{2}{|c|}{ Produkcja globalna } & 74,8 & 84,5 & 97,4 & 99,4 \\
\hline \multirow{2}{*}{ w tym: } & produkcja roślinna & 79,6 & 76,2 & 92,8 & 93,4 \\
\cline { 2 - 6 } & produkcja zwierzęca & 68,1 & 96,1 & 103,8 & 107,7 \\
\hline $\begin{array}{l}\text { Produkcja na 1 stałego } \\
\text { pracownika w sektorze rolnym }\end{array}$ & 109,0 & 162,5 & 174,5 & 193,0 \\
\hline $\begin{array}{l}\text { Produkcja globalna na } \\
\text { 1 ha użytków rolnych }\end{array}$ & 78,3 & 89,4 & 103,8 & 105,9 \\
\hline \multirow{2}{*}{ w tym: } & produkcja roślinna & 83,3 & 80,6 & 98,9 & 99,5 \\
\cline { 2 - 6 } & produkcja zwierzęca & 71,3 & 101,6 & 110,5 & 114,8 \\
\hline
\end{tabular}

Uwaga: *Produkcja rolnicza była porównywana z rokiem $1936=100 \%$

Źródło: AMSZ, DI.WCz, Czechosłowacja 232, t. 450, wiązka 49, s. 228, Notatka o rolnictwie czechosłowackim w 1959 roku.

W I959 r. po zakończeniu procesu kolektywizacyjnego władze czechosłowackie zniosły niskie ceny płacone dotychczas spółdzielniom za produkty rolne odstawiane do punktów skupu. Natomiast nie zwolniono chłopów od dostaw obowiązkowych dla państwa z działek przyzagrodowych. Ostatecznie, pod koniec lat 50. Xxw. władze wprowadziły wyższe ceny za produkty rolne. Miało to na celu doprowadzić do podwyższenia zarobków w spółdzielniach. Oczekiwano, że dalszym następstwem tego procesu będzie zahamowanie „tendencji do uprawy własnych działek przyzagrodowych na rzecz kolektywnych”, czyli Rolniczych Spółdzielni Produkcyjnych ${ }^{42}$.

Na przełomie lat 50. i 60. XXw., po zakończeniu procesu kolektywizacyjnego, rolnicza produkcja globalna osiągnęła prawie poziom przedwojenny. Jeżeli przyjąć produkcję w roku 1936 za I00\%, to w I958 r. wynosiła ona około 99\%. Jak z tego wynikało, dziesięcioletni proces tworzenia socjali-

4I AMSZ, DI.WCz, Czechosłowacja 252, t. 450, wiązka 49, s. I 44, Notatka z III Ogólnopaństwowego Zjazdu...; J. Pernes, Závèrečná etapa..., s. 9-22.

42 Ofensywa kolektywizacji w Europie Wschodniej, "Jutro Polski”, 26 vi 1959, nr I8; V. Březina, Poslední..., s. 69-90. 
stycznego rolnictwa nie przyniósł zwiększenia produkcji rolniczej w Czechosłowacji w stosunku do okresu przedwojennej gospodarki kapitalistycznej. W tym czasie nastąpiła długoletnia stagnacja.

W 1959 r. nadal rozszerzano sektor socjalistyczny. Obszar użytków rolnych należących do PGR powiększył się o 62 tys. ha i osiągnął poziom ponad jednego mln ha. Nadal, chociaż wolniej niż w latach ubiegłych, wzrastała ilość ziemi spółdzielczej. W końcu 1958 r. funkcjonowało I2,56 tys. spółdzielni produkcyjnych, do których należało $4,8 \mathrm{mln}$ ha użytków rolnych (łącznie z działkami przyzagrodowymi). U schyłku lat 50. XX w. z powodu procesu łączenia spółdzielni ich ilość wyraźnie się zmniejszała. Od jesieni I958 r. do końca lutego I959 r. I579 spółdzielni połączyło się w 659 większych. Dotychczas spółdzielnie posiadały przeciętnie po około 300 ha ziemi ornej, ale od roku i958 władze państwowe dążyły do utworzenia spółdzielni o przeciętnej powierzchni od 500 do 700 ha.

Zgodnie z planem likwidacji rolnictwa indywidualnego do końca $1958 \mathrm{r}$. kolektywizacja w Czechosłowacji została zakończona. Pod koniec 1958 r. do chłopów indywidualnych należało jeszcze około 15,6\% użytków rolnych, czyli około I, 4 mln ha. Z tego obszaru około $72 \%$ przypadało na gospodarstwa o powierzchni od 2 do is ha, około $3 \%$ na gospodarstwa powyżej is ha, a $25 \%$ na gospodarstwa karłowate do 2 ha. Jak się okazało, najwięcej trudności sprawiała władzom kolektywizacja gospodarstw karłowatych, ponieważ ich właściciele kurczowo trzymali się swojej własności i nie chcieli oddać jej w ręce spółdzielni. Drobni rolnicy wbrew władzom czechosłowackim byli zdecydowanymi przeciwnikami kolektywizacji wsi. Jeszcze na początku 1958 r. w całym kraju istniało 897,5 tys. gospodarstw karłowatych. Reżym komunistyczny zastosował wobec nich groźby, represje ekonomiczne i terror bezpośredni. W wyniku tych działań do końca września do spółdzielni włączono I 84655 gospodarstw. Mimo tego drobni rolnicy nadal opierali się kolektywizacji i jeszcze na przełomie lat 1958 i 1959 gospodarowali indywidualnie na obszarze blisko 350 tys. ha. Jednak ich opór w końcu złamano, a gospodarstwa siłą włączono do spółdzielni lub PGR ${ }^{43}$. W niektórych miejscowościach przedstawiciele władz komunistycznych mówili wprost, że „drobnych rolników przy dzisiejszym poziomie ich życia, nie można pozyskać do spółdzielni. Drobni rolnicy byli nawet uważani za wrogów socjalistycznej przebudowy wsi" ${ }^{44}$. Niski poziom

43 AMSZ, DI.WCz, Czechosłowacja 252, t. 450, wiązka 49, s. 232, Notatka z III Ogólnopaństwowego Zjazdu...; W. Misiuna, dz. cyt., s. 170-174, 176-185; A. Kita, W. Jurek, A. Niedźwiedzki, Spótdzielczość produkcyjna wświetle ustawodawstwa i doświadczeń, Warszawa 1956, s. 4I-48; J. Urban, Venkov..., s. 54-56, 59-126, 131-198. Autor ten opisał gehennę czechosłowackich rolników, męczonych, prześladowanych, wysiedlanych, więzionych i lżonych przez komunistyczne państwo czechosłowackie. W wyniku takich działań pod koniec lat 50 . wiele wsi czechosłowackich stało się w pełni skomunizowanymi.

44 AMSZ, DI.WCz, Czechosłowacja 252, t. 450, wiązka 49, s. 232, Notatka z III Ogólnopaństwowego Zjazdu... 
kolektywizacji gospodarstw karłowatych wyjaśniano następującymi przyczynami: „a) do tej pory nastawiano się głównie na kolektywizację średnich i małych a nie karłowatych gospodarstw, b) dochody uzyskiwane z gospodarstw karłowatych są wysokie i wobec tego atrakcyjność niektórych spółdzielni jest mała" ${ }^{45}$. Niechęć właścicieli gospodarstw karłowatych do przystępowania do spółdzielni rolniczych była spowodowana utratą dodatkowych dochodów powodujących ich zubożenie. Władze komunistyczne nie przyjmowały owej argumentacji. Konsekwentnie realizowały swój plan kolektywizacyjny.

TAB. 7 Wydajność gospodarstw karłowatych w 1958 r. w stosunku do ogółu gospodarstw rolnych w Czechosłowacji (w procentach)

\begin{tabular}{|c|c|c|c|c|}
\hline Rodzaj gospodarstwa & Bydło & Krowy & Świnie & Drób \\
\hline Gospodarstwa karłowate & 67,8 & 44,9 & 90,9 & 658 \\
\hline Przeciętna krajowa & 56,6 & 28,5 & 75,2 & 335 \\
\hline
\end{tabular}

Źródło: AMSZ, DI.WCz, Czechosłowacja 232, t. 450, wiązka 49, s. 228, Notatka o rolnictwie czechosłowackim w 1959 roku.

Zgodnie z przyjętą polityką rolną władze Czechosłowacji dążyły do włączenia do spółdzielni przede wszystkim tych drobnych rolników, których głównym źródłem utrzymania były gospodarstwa małe. W sytuacji niedoboru pracowników w istniejących spółdzielniach, nakazywały podjęcie w nich pracy rodzinom pracowników zatrudnionych w przemyśle i budownictwie oraz rencistom - posiadaczom gospodarstw karłowatych. Ponadto zezwoliły na zatrudnienie w spółdzielniach byłych właścicieli gospodarstw, których klasyfikowały jako należących do „warstwy wyzyskiwaczy”. U schyłku lat 50. przyjmowano ich „do spółdzielni na takich samych warunkach jak i kułaków, między innymi z prawem możności pełnienia funkcji" 46 .

Komunistyczne władze Czechosłowacji dążyły do skolektywizowania nawet najmniejszych gospodarstw. Na przełomie lat 50. i 60., głównie przy użyciu instrumentów ekonomicznych, scalono małe spółdzielnie. W ramach prowadzonych inwestycji w spółdzielniach rozbudowano sferę usług socjalnych i kulturalnych. Włączono do pracy kobiety.

W propagandzie kołchozowej mówiono o objęciu powszechnymi ubezpieczeniami i opieką lekarską pracowników gospodarstw spółdzielczych.

45 Tamże, s. 233-234. Szerzej zob.: W. Misiuna, dz. cyt., s. 174-198; I. Rubik, Rolnictwo w Czechostowacji, Warszawa 1966, s. 24-34.

46 AMSZ, DI.WCz, Czechosłowacja 252, t. 450, wiązka 49, s. 232-234, Notatka z III Ogólnopaństwowego Zjazdu...; Závěrečná fáze..., s. 22-52; J. Pešek, Obrat..., s. 497-498, 508-509. 
W spółdzielniach rozbudowano przedszkola, żłobki, szkoły, świetlice, kluby kulturalne, kina itp. Władze twierdziły, że „tego wszystkiego na wsi sprzed 1948 r. nie było" 47 .

W końcu lat 50. władze dążyły do tego, aby, jak pisał polski dyplomata, „spółdzielnie produkcyjne coraz bardziej zabezpieczały spółdzielcom mleko i warzywa, wobec tego działka przyzagrodowa coraz bardziej traciła swoje znaczenie" ${ }^{8}$. Władze komunistyczne za pośrednictwem kierownictw spółdzielni „,coraz więcej naciskały w kierunku całkowitej likwidacji działek przyzagrodowych, dążąc do tego, aby spółdzielca cały czas poświęcał pracy w spółdzielni oraz jego byt był w pełni uzależniony od wyników pracy kolektywnej" ${ }^{49}$. Wszystkie zmiany wprowadzone wówczas przez władze Czechosłowacji miały na celu ,podniesienie produkcji rolnej w sektorze socjalistycznej gospodarki rolnej, a w szczególności zwiększenie zainteresowania spółdzielców w wydajność pracy i obniżeniu kosztów własnych produkcji"so. Wdrażając nowy system planowania polegający na wprowadzeniu planów pięcioletnich, stworzyły ich zdaniem „warunki dla zwiększenia samodzielności spółdzielni produkcyjnych. „Zwiększenie samodzielności” w systemie socjalistycznej gospodarki polegało głównie na „wprowadzaniu wieloletnich umów spółdzielni z przedsiębiorstwami skupu na dostawy produktów rolnych"si. W tym też celu dla ułatwienia transakcji „wprowadzono jednolite ceny” na produkty rolne wyhodowane w spółdzielniach rolniczych ${ }^{52}$. Dotychczas bowiem obowiązywały podwójne ceny: niskie na obowiązkowe dostawy i nieco wyższe stosowne podczas skupu produktów rolnych.

Na przełomie lat 50. i 60. spółdzielcom nakazano wykupić sprzęt rolniczy z POM-ów, ponieważ instytucje te jako deficytowe likwidowano. Spółdzielnie miały też ponosić dodatkowe wydatki w związku ze zlikwidowaniem przydziałów pasz dla spółdzielni produkcyjnych z funduszu centralnego. W tym okresie znaczna część spółdzielni ponosiła również dodatkowe

47 AMSZ, DI.WCz, Czechosłowacja 252, t. 450, wiązka 49, s. 234, Notatka z III Ogólnopaństwowego Zjazdu...; I. Rubik, dz. cyt., s. 173-197; V. Forst, dz. cyt., s. I64.

48 AMSZ, DI.WCz, Czechosłowacja 252, t. 450, wiązka 49, s. 234, Notatka z III Ogólnopaństwowego Zjazdu...

49 Tamże.

50 Tamże.

5I Tamże, s. 235 .

52 Szerzej zob.: W. Misiuna, dz. cyt., s. 174-198; I. Rubik, dz. cyt., s. 124-I43, 185-190; J. Pešek, Reorganizácia strojových a traktorových stanic v Československu v rokoch I959-1969, „Historičky Časopis” 1985, č. 3, s. 371-395; M. Barnovský, Prestávka medzi prvou a druhou etapou kolektivizáacie, [w:] Osudy zemédèlského družstvenictví ve 2o. století. Sborník príspevkù z mezinárodní konference konanéve dnech Is-I6 kvètna 2002. Vènovaný Lubomíru Slezákovi k. 7o. narozeninám, „Studie Slovackeho Muzea” 2002, č. 7, s. 235-237 (Uherské Hardiště). 
obciążenia w związku z w prowadzeniem nowego systemu podatku dochodowego. Do 1959 r. podatek wynosił I-2\% dochodu spółdzielni, a od I960 r. jego skala została podniesiona do I $-7 \%$ dochodu spółdzielni ${ }^{53}$.

W końcu 1958 r. we wszystkich spółdzielniach rolniczych została przeprowadzona powszechna inwentaryzacja środków trwałych. Inwentaryzacja ta stanowiła podstawę do, jak to ujęto, „prawidłowego ustalenia odpisów amortyzacyjnych"s4. Miała ona duże znaczenie, zwłaszcza po zakupieniu przez spółdzielnie maszyn rolniczych. Wyniki inwentaryzacji w niektórych spółdzielniach wskazywały, że „dla zapewnienia reprodukcji rozszerzonej”ss potrzebne było zwiększenie wpłat na fundusz niepodzielny w wysokości $20 \%$ całkowitych dochodów spółdzielni. Należy dodać, że statut przewidywał tylko ı०\%. Sytuacja taka spowodowana została radykalnym uspółdzielczeniem wsi i w konsekwencji doprowadziła do wzmożonego zapotrzebowania na środki finansowe niezbędne dla coraz większych obszarowo gospodarstw ${ }^{56}$.

Regulacje podatkowe spowodowały, że w 1959 r. zjednego hektara użytków rolnych na fundusz niepodzielny wpłacano $42 \mathrm{I}$ Kčs. Jak uważali analitycy gospodarczy, był to wzrost bardzo duży. Rok wcześniej na ten fundusz wpłacano tylko 295 Kčs z jednego hektara użytków, a nawet, na początku tego roku 249 Kčs. Jak z tego wynikało, był to wzrost na poziomie między $43 \%$ a $69 \%$. Konieczność zwiększenia przydziałów na fundusz niepodzielny wypływała także z tego, że „udział własnych środków finansowych spółdzielni w budownictwie inwestycyjnym, zakupie maszyn, remontach generalnych i zakupie bydła hodowlanego wynosi do tej pory tylko $27,2 \%$. Wzrost dotacji na fundusz niepodzielny wpłynął na zmniejszenie się dniówki obrachunkowej. W 1959 r. dniówka obrachunkowa łącznie z „naturaliami” zmniejszyła się z I9,2 do 17,42 Kčs. Spadek wartości dniówki obrachunkowej odbywał się „przy równoczesnym wzroście wartości produkcji na I hektarze użytków rolnych z 3239 Kčs. w 1958 roku na 3377 Kčs.” W 1959 r. o wzroście zadecydowała produkcja zwierzęca. Oznaczało to, że „o spadku wysokości dniówki obrachunkowej zadecydowały zwiększone odpisy na fundusz niepodzielny”. W ten sposób rolnicy pracujący w rolniczych spółdzielniach produkcyjnych byli wyzyskiwani przez państwo. Ponosili koszty gwałtownej i nieprzemyślanej industrializacjis7.

53 AMSZ, DI.WCz, Czechosłowacja 232, t. 450, wiązka 49, s. 235, Notatka o rolnictwie czechosłowackim I 1959; K. Jech, Soumrak selského stavu 1945-1960, Praha 2001, s. 157-159; Smérnice ústředního výboru KSČ pro sestaveni droubeho pètiletého plánu rozvoje národního hospodárstvi ČsR na leta 1956-Ig6o, [w:] OdX. do XI. Sjezdu KSČ. Usneseni a dokumenty UV KSČ, Praha 1958, s. 373-383.

54 AMSZ, DI.WCz, Czechosłowacja 232, t. 450, wiązka 49, s. 236, Notatka o rolnictwie czechosłowackim I 1959.

55 Tamże.

56 Tamże; J. Pešek, Reorganizácia..., s. 371-395.

57 AMSz, DI.WCz, Czechosłowacja 232, t. 450, wiązka 49, s. 236, Notatka o rolnictwie czechosłowackim I 1959; J. Pernes, Závérečná etapa..., s. il-28. 
W Czechosłowacji wprowadzono zatem, wzorowany na sowieckim, sposób wynagrodzenia spółdzielców. Po przetestowaniu kilku wariantów ostatecznie wybrano ten, w którym „gwarantowano zaliczkowanie spółdzielcom wypłat na poczet dniówek obrachunkowych". Miesięczne zaliczki wypłacano „w jednakowej z góry ustalonej wysokości w ciągu całego roku”. W końcu roku następowało całkowite rozliczenie z pracownikiem spółdzielni ${ }^{58}$.

Rok 1959 przyniósł również reorganizację zadań z zakresu zarządzania produkcją rolną realizowanych przez lokalne rady narodowe. Rady narodowe nadal zarządzały państwowymi gospodarstwami rolnymi i РОм dopóki istniały, a także kontrolowały produkcję spółdzielni rolniczych. Rady te „zawiadywały” też szkolnictwem rolniczym w powiecie. Na przełomie lat 50. i 60. XX w. władze zobowiązały naukowców i fachowców zajmujących się organizacją produkcji rolnej do wspomagania socjalistycznego rolnictwa ${ }^{59}$.

Mimo ciągłej mechanizacji rolnictwa nadal wiele prac polowych wykonywano ręcznie lub przy użyciu koni jako siły pociągowej. W przeciętnej rolniczej spółdzielni produkcyjnej na jednego pracownika przypadało wówczas do obrobienia - w okresie nasilonych "terminów agrotechnicznych" - 4,5 ha ziemi. Pracownicy spółdzielni rolniczych byli zatem mocno obciążeni pracą, często ponad ich siły. W 1959 r. nadal aż 89 hektarów użytków rolnych przypadało do obrobienia na jeden traktor. W tej sytuacji, jak wynikało z danych statystycznych, nadal około I/ 3 ziemi była obrabiana konno. W końcu lat 50. przeprowadzono akcję mechanizacji rolnictwa, która doprowadziła do zwiększenia w spółdzielniach produkcyjnych liczby traktorów i maszyn rolniczych. Równocześnie zmniejszony został obszar użytków rolnych, które musiał obrobić przeciętny spółdzielca ${ }^{60}$.

W wyniku przeprowadzonej kolektywizacji wsi czechosłowackiej na początku lat 60. XX w. osiągnięto pełne jej „usocjalistycznienie”. Z terenów wiejskich zniknęli indywidualni gospodarze. Stało się to w kraju, który do $1948 \mathrm{r}$. miał w tej części Europy najlepiej rozwinięte rolnictwo. Według ocen fachowców w 1938 r. czechosłowackie gospodarstwa chłopskie osiągnęły poziom rolnictwa belgijskiego. W I 948 r. rolnicy czechosłowaccy ponownie osiągnęli ten poziom. W wyniku siłowego przebranżowienia tego działu gospodarki, powstania rolniczych spółdzielni produkcyjnych oraz PGR, zniszczeniu uległa

58 AMSZ, DI.WCz, Czechosłowacja 232, t. 450, wiązka 49, s. 237, Notatka o rolnictwie czechosłowackim I 1959; J. Burešová, Zemědělství..., s. 197-199; A. Václavů, Ke spori̊m..., s. 29-30; I. Rubik, dz. cyt., s. I24-I 43, I65-I73; V. Forst, dz. cyt., s. I57-I6I.

59 AMSz, DI.WCz, Czechosłowacja 232, t. 450, wiązka 49, s. 238, Notatka o rolnictwie czechosłowackim I 1959; Ch. Bouvier, La collectivisation de l'agriculture. U.R.S.S., Chine, Démocraties populaires, Warszawa 1958, s. 2, 15-20.

60 AMSz, DI.WCz, Czechosłowacja 232, t. 450, wiązka 49, s. 238, Notatka o rolnictwie czechosłowackim I 1959; Ch. Bouvier, dz. cyt., s. 21-36, 82-90, I28-I36; I. Rubik, dz. cyt., s. 62-I26. 
grupa zawodowych rolników indywidualnych. W wyniku prowadzonejwówczas polityki rolnej znacznie obniżyła się produkcja rolna. W latach 1936-1938 plony buraków cukrowych z jednego hektara wynosiły około 300 q, a w 1962 roku były one o I2 q niższe ${ }^{61}$. Przed wojną plony ziemniaków osiągały I35 q z I ha, natomiast w I96I r. w czechosłowackich „kołchozach” i „sowchozach” zebrano przeciętnie około Io9 q z I ha. W I938 r. ogólna produkcja ziemniaków wyniosła 9,6 mln ton, a w 1962 r. zebrano tylko 5,6 mln ton ${ }^{62}$. Nastąpił więc widoczny spadek wydajności. W wyniku niskich plonów w miastach, a nawet na wsi, zaczęło brakować żywności. Na przełomie lat 50. i 60. XX w. można było zaobserwować załamanie się hodowli bydła. W 1938 r. w Czechosłowacji zanotowano $2,4 \mathrm{mln}$ krów, a w $1960 \mathrm{r}$. było ich około $2 \mathrm{mln}^{63}$.

Podobnie, tendencja spadkowa dotyczyła wydajności mlecznej krów. Do I948 r. wydajność ta wynosiła rocznie około 2 tys. litrów, zaś „spółdzielczo-pegerowskie" krowy dawały do I,8 tys. litrów mleka rocznie ${ }^{64}$. Zmiany zaszły także w hodowli trzody chlewnej; na wyhodowanie soo kg tucznika rolnicy indywidualni potrzebowali dwieście, zaś spółdzielcy trzysta dni. Drastycznie spadała hodowla drobiu - z $40 \mathrm{mln}$ do około $28 \mathrm{mln}$ sztuk. Spadek hodowli spowodował na rynku żywnościowym niedobory mięsa drobiowego, wieprzowego, wołowego, wyrobów mlecznych, jajek, a nawet chleba ${ }^{65}$.

W latach 60. XX w. członek Komitetu Centralnego KPCz odpowiedzialny za rolnictwo, Jiří Hendrych, twierdził, że przyrost produkcji w rolnictwie wynosił ı\% rocznie. $Z$ tego powodu wiele tysięcy hektarów ziemi leżało odłogiem, co spowodowało wspomniany spadek produkcji zbóż. Należy dodać, że podczas zbiorów setki tysięcy ton zbóż, ziemniaków, buraków zmarnotrawiono, ponieważ niedokładnie je zbierano ${ }^{66}$. Przypomnijmy, że na początku lat 6o. Xxw. przeprowadzono w Czechosłowacji „scalenie” spółdzielni rolniczych na wzór sowiecki, tworząc gospodarstwa o powierzchni kilkuset hektarów. J. Hendrych oceniał, że akcja ta spowodowana została „złą uprawą gleby, lichym ziarnem siewnym, niedbałą pielęgnacją

6I M. C., Wyniki „socjalistycznego” rolnictwa w Czechostowacji, „Jutro Polski”, I8 vi 1962, nr I8; A. Václavů, Ke sporưm..., s. 20-30; tenże, O agrární otázce v socialistickém hnutí, „Revue Dějin Socialismu" 1968, č. I, s. 5-58; W. Misiuna, dz. cyt., s. 175-185.

62 M. C., Wyniki...; Rozvoj..., s. I0, I5; Rozwój gospodarki krajów Rady Wzajemnej Pomocy Gospodarczej w latach 1950-1968, Warszawa 1969, s. 83.

63 Wiele krów zdechło z powodu gruźlicy. Zob. M. C., Wyniki...; W. Misiuna, dz. cyt., s. I83; V. Březina, Kolektivizace zèmédělství..., s. I28-135.

64 M. C., Wyniki...; W. Misiuna, dz. cyt., s. 194; Statistickěprehledy v ČSR a zahraničízemedelstvi, „Zemědělská Ekonomika” 1969, č. I, tab. XIII.

65 M. C., Wyniki...; W. Misiuna, dz. cyt., s. 183-194; Statistickěprehledy v ČsR a zahraničkim zemedelstvi, „Zemědělská Ekonomika” 1969, č. I, tab. XI; Statistická ročenka ČSSR 1970, Praha 1970, s. 294.

66 M. C., Wyniki...; I. Rubik, dz. cyt., s. 49-6I, 94-I23; V. Forst, dz. cyt., s. 156-162; J. Rychlík, dz. cyt., s. 189-192, 197-20I. 
rośli, złym wykorzystaniem maszyn i środków transportu, niedostateczną organizacją pracy" ${ }^{67}$. Jednak zasadniczą przyczyną spadku produkcji rolnej było „odebranie chłopom ziemi, zniszczenie wolnej spółdzielczości, zniszczenie w ten sposób inicjatywy chłopskiej oraz ochoty do pracy"68.

$\mathrm{Na}$ początku lat 6o. w krajach obozu socjalistycznego mimo prób odebrania chłopom działek zagrodowych, ci nadal trzymali je kurczowo w swych rękach. Komuniści w Czechosłowacji, podobnie jak niemieccy komuniści w NRD, „dogmatyczni, nadgorliwi, co się zowie, zdecydowanie występowali przeciw działkom i zaczęli już je likwidować, poczynając od bardziej opanowanych przez siebie, czyli jak się to mówiło umocnionych [tam gdzie byli liczni komuniści] kołchozów"69. Mimo takich zamiarów komuniści, obawiając się oporu rolników-spółdzielców, zezwolili na posiadanie przez nich półhektarowych działek. W rejonach górskich działki takie miały około hektara - faktycznie zaś jedynie pięćdziesiąt arów ziemi ornej. Jak pisano wyżej, możliwości prowadzenia na nich hodowli były ustawowo ograniczone ${ }^{70}$. Nastąpiło znaczne ubezwłasnowolnienie czechosłowackich chłopów - zabrano im wolność polityczną i gospodarczą, uzależniono całkowicie od administracji państwowej, która nadzorowała ich działalność gospodarczą.

\section{Represje wobec chłopów czechosłowackich}

W zakresie kolektywizacji wsi czechosłowaccy komuniści działali według wypróbowanego sowieckiego wzorca ${ }^{71}$. Jak już wspomniano, uspółdzielczenie wsi rozpoczęto w 1949 r. Początkowo organizowano spółki maszynowe i proste typy spółdzielni. Wiele uwagi poświęcono pracy wśród kobiet. Organizowano pralnie, kursy gospodarstwa domowego. Dzięki temu kobiety miały „spełniać dużą rolę” w przebudowie wsi. „Ogromną pomoc” $\mathrm{w}$ tym procesie okazali robotnicy zamieszkali na wsi, a pracujący w wielkich zakładach produkcyjnych. Należy pamiętać, że w Czechosłowacji nie było: „prawie wsi, w której nie mieszkaliby robotnicy pracujący w przemyśle” ${ }^{22}$.

67 M. C., Wyniki...; W. Misiuna, dz. cyt., s. 173. Dane o scalaniu JzD zob.: „Zemědělska Ekonomika” 1961, č. 3.

68 M. C., Wyniki...; Masakrv Litobořri - 28 XII I95I, [w:] M. Karelová, Tajemná mista komunismu. Fascinujici mista české historie, Brno 2017; Pomnik násilně vystěhovaným sedlákủm ve Lhotce $v$ Akce „Kulak” (I95I-I954), [w:] M. Karelová, dz. cyt., s. 202.

69 M. C., Sita chtopskiej ziemi, „Jutro Polski”, Io vi 1962, nr I0-II; W. Misiuna, dz. cyt., s. 161-174, 207.

70 M. C., Sita...; J. Urban, Venkov..., s. 106-116, 153-175, 243-276.

7I M. C., Sita...; J. Burešová, Kolektivizace jako..., s. I09-II8; V. Forst, dz. cyt., s. 68-69, 153-167.

72 AMSZ, DI.WCz, Czechosłowacja 232, t. 450, wiązka 49, s. 290, Notatka z pobytu w ČsR delegacji PZPR dla zapoznania się z rolnictwem czechosłowackim, lipiec 1960 r.; B. Strużek, dz. cyt., s. 54-68. 
ROMUALD tURKowsKı Następstwa społeczno-gospodarcze kolektywizacji wsi czechosłowackiej...

W'sód owych robotników było wielu komunistów, którzy z wielką determinacją z polecenia KPCz uczestniczyli w kolektywizacji wsi ${ }^{73}$. Podjęto bezwzględną walkę z chłopami. W I949 r. komunistyczne „grupy kolektywizacyjne" uczestniczyły w zajmowaniu maszyn rolniczych, karały chłopów indywidualnych za zatrudnianie robotników rolnych i rzekome ich wyzyskiwanie. Właściciele większych gospodarstw rolnych i ich rodziny wysiedlano z gospodarstw, skazując na głód i poniewierkę. Dotknęło to kilkaset tysięcy osób uznanych przez komunistów za „kułaków”74. Proces tzw. wykupywania, czyli zajmowania chłopskiego mienia przez władze państwowe przedstawiono w tabeli nr 8.

TAB. 8 Przymusowy wykup maszyn rolniczych i traktorów z gospodarstw indywidualnych w latach 1950-195I

\begin{tabular}{|c|c|c|c|c|}
\hline \multirow[b]{2}{*}{ Rodzaj maszyn } & \multicolumn{3}{|c|}{ Liczba wykupionych maszyn na terenie } & \multirow{2}{*}{$\begin{array}{l}\text { Przydzielono } \\
\text { spółdzielniom }\end{array}$} \\
\hline & $\begin{array}{c}\text { ziem } \\
\text { czeskich }\end{array}$ & $\begin{array}{c}\text { ziem } \\
\text { słowackich }\end{array}$ & ogółem & \\
\hline Traktory & 12485 & 3906 & 16391 & 3733 \\
\hline Snopowiązałki & 20141 & 224 & 20365 & 6478 \\
\hline Młocarnie & 15946 & 7068 & 23014 & 6390 \\
\hline Przyczepy & 5525 & 848 & 6373 & 2637 \\
\hline Prasy & 9992 & 180 & 10172 & 3265 \\
\hline Lokomobile & 865 & 740 & 1596 & 160 \\
\hline Silniki elektryczne & 9896 & 1840 & 12736 & 3815 \\
\hline Samochody ciężarowe & 110 & 140 & 250 & 23 \\
\hline
\end{tabular}

Źródło: B. Strużek, Rolnictwo europejskich krajów socjalistycznych.

Problemy spoteczno-ekonomiczne, Warszawa 1963, s. 67.

Po upadku reżymu komunistycznego jeden z dotkniętych prześladowaniami mieszkańców wsi czeskiej Miloslav Růžička zebrał i opublikował 205 relacji rolników lub członków ich rodzin, w których ludzie ci opowiedzieli o swoich dramatycznych losach podczas kolektywizacji wsi. Niemal we wszystkich relacjach znalazły się opisy prześladowań, szykan i dręczenia niewinnych ludzi przez aparat komunistyczny. M. Růžička zdołał zgromadzić tak obszerny i różnorodny oraz przekonywujący materiał relacyjny, że może on być traktowany

73 AMSZ, DI.WCz, Czechosłowacja 232, t. 450, wiązka 49, s. 291, Notatka z pobytu w ČsR ... lipiec I960 r.; V. Forst, dz. cyt., s. 290-296.

74 P. Blažek, M. Kubálek, Akce „Kulak”. Přijetí, uplatňovánía zrušeni smérnice tři ministrů,[w:] P. Blažek i in., Akce „K”..., s. 6I-I5I. 
jako całościowy obraz losu rolników czechosłowackich gnębionych przez reżym komunistyczny. Komuniści czechosłowaccy stosowali brutalne metody zaczerpnięte ze stalinowskiego arsenału rozprawiania się z chłopami.

W 1956 r. w okręgu budziejowickim odbyły się setki procesów sądowych przeciwko chłopom oskarżonym o sabotowanie obowiązkowych dostaw i prowadzenie dywersji przeciwko komunizmowi. Na terenie Południowych Czech proces ten był niezwykle nasilony. W tej części kraju znajdowały się bowiem duże dobrze prosperujące gospodarstwa rolne. Władze komunistyczne poddały gospodarujących na nich rolników wymyślnym prześladowaniom. Wśród dziesiątek tysięcy uciemiężonych przez aparat komunistyczny był między innymi Jan Kojan i jego żona, pochodzący z Šalmanovic w powiecie České Budějovice. Rolnika tego, gospodarującego na 75-hektarowym wielkoobszarowym gospodarstwie rolnym obłożono podatkami, czyli tzw. domiarem, w wysokości 30 tys. Kčs. Władze komunistyczne nakazały wpłacenie pieniędzy w trybie natychmiastowym. Z powodu niewykonania tej drakońskiej kary w $1952 \mathrm{r}$. rodzinę Kojanów usunięto z gospodarstwa. Rolnik został uwięziony w ciężkim obozie pracy. W $1955 \mathrm{r}$. zezwolono mu wrócić do domu, ale do tego czasu jego wielkie gospodarstwo rozgrabiono i zniszczono. Dopiero w 1989 r. zrehabilitowano go i oddano gospodarstwo. Mimo ogromu cierpień władze czeskie nie zadośćuczyniły krzywdom, jakich J. Kojan i jego rodzina doznali ze strony komunistycznego państwa czechosłowackiego ${ }^{75}$.

Podobny los dotknął Františka Pospišila z Mezholezy koło Kutnej Hory, któremu odebrano 6o-hektarowe gospodarstwo. Więziono jego i żonę. Podczas napadu „komunistycznych hord” żona F. Pospišila doznała ataku serca i nagle zmarła. Jak pisał po latach jej syn, „maminka svŭj podpis nedokončila, klesla k zemi mrtvá" ${ }^{6}$. Podobnym prześladowaniom poddani byli liczni rolnicy z Środkowych Czech. Wśród nich był pochodzący ze starego rodu chłopskiego Rudolf Rehak ze wsi Lipany - więziony, szykowany, pozbawiony gospodarstwa. W $1968 \mathrm{r}$. nie zdążono go rehabilitować. Stało się to w 1991 r. Wówczas oddano mu 27-hektarowe gospodarstwo. Pracy nad jego odbudową podjął się dopiero jego wnuk Jiřii Řehak, żyjący

75 J. Kojan (Šalmanovice). [Wspomnienie o tragicznych losach rolnika Jana Kojana, opowiedziane przez jego prześladowanego syna], [w:] M. Růžička, Vyhnanci II. Akce „Kulak”, zločin proti lidskosti, Havličkův Brod 2011, s. 40-43; V. Hlavová, Policajno-administratívny a ekonomický nátlak na rolnikom počas I. etapy kolektivizácie, [w:] Od diktatúry k diktatúre. Slovensko v rokoch 1945-1953, red. M. Barnovský, Bratislava 1995, s. 172-180.

76 F. Pospišil (Mezholezy k/Kutnej Hory). [Relacja syna], [w:] M. Růžička, Vyhnanci I. Akce „Kulak", zločin proti lidskosti, Harličkủv Brod 2008, s. 249-25I; [Relacja nr 69], [w:] P. Blažek, M. Kubálek, Akce „Kulak”..., s. 78-199. 
RomUALD tuRKowsKı Następstwa społeczno-gospodarcze kolektywizacji wsi czechosłowackiej...

TAB. 9 Prześladowania ekonomiczno-propagandowe rolników czechosłowackich w latach 50. Xx wieku

\begin{tabular}{|c|c|c|c|c|c|c|}
\hline $\begin{array}{c}\text { Geograficzny } \\
\text { przekrój } \\
\text { prześladowań }\end{array}$ & $\begin{array}{c}\text { Liczba } \\
\text { relacji }\end{array}$ & $\begin{array}{c}\text { Kary } \\
\text { pieniężne }\end{array}$ & $\begin{array}{c}\text { Zwięk- } \\
\text { szone } \\
\text { podatki }\end{array}$ & $\begin{array}{c}\text { Rabunek } \\
\text { mienia }\end{array}$ & $\begin{array}{c}\text { Ataki } \\
\text { propagan- } \\
\text { dowe }\end{array}$ & $\begin{array}{c}\text { Powrót na } \\
\text { gospodarstwo } \\
\text { po 1989 roku }\end{array}$ \\
\hline Czechy Środkowe & 25 & 25 & 25 & 25 & 15 & 5 \\
\hline Czechy Zachodnie & 10 & 10 & 10 & 10 & 5 & 3 \\
\hline Czechy Wschodnie & 11 & 11 & 11 & 11 & 7 & 3 \\
\hline Czechy Północne & 11 & 11 & 11 & 11 & 4 & 2 \\
\hline Czechy Południowe & 26 & 26 & 26 & 26 & 15 & 7 \\
\hline Stowacja & 2 & 2 & 2 & 2 & 1 & 1 \\
\hline Razem & 85 & 85 & 85 & 85 & 48 & 21 \\
\hline
\end{tabular}

Uwaga: W dwóch tomach przywołanego niżej wydawnictwa M. Růžička zamieścił 205 relacji. Do opracowania tabeli wykorzystano 85 relacji, dobierając je pod względem geograficznym i zawartości treści.

Źródło: M. Růžička, Vyhnanci I i II. Akce „Kulak”, zločin proti lidskosti, t. I-II, Havličkův Brod 2008-20ı I, passim.

TAB. 10 Działania terrorystyczne - prześladowania prowadzone przez władze komunistyczne wobec rolników czechosłowackich w latach 50. XX wieku

\begin{tabular}{|c|c|c|c|c|c|c|c|}
\hline $\begin{array}{c}\text { Geografia } \\
\text { prześladowań }\end{array}$ & 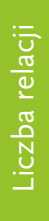 & 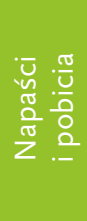 & 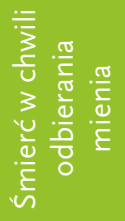 & 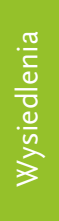 & 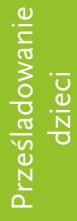 & 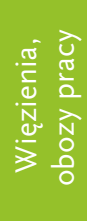 & 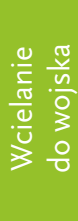 \\
\hline Czechy Środkowe & 25 & 15 & 3 & 20 & 15 & 20 & 3 \\
\hline Czechy Zachodnie & 10 & 7 & 2 & 10 & 7 & 8 & 1 \\
\hline Czechy Wschodnie & 11 & 8 & 2 & 9 & 7 & 9 & 2 \\
\hline Czechy Północne & 11 & 9 & 1 & 9 & 8 & 7 & 1 \\
\hline Czechy Południowe & 26 & 16 & 4 & 20 & 20 & 20 & 4 \\
\hline Słowacja & 2 & 1 & - & 1 & 1 & 1 & - \\
\hline Razem & 85 & 56 & 12 & 69 & 58 & 65 & 11 \\
\hline
\end{tabular}

Źródło: M. Růžička, Vyknanci I i II. Akce „Kulak”, zločin proti lidskosti, t.I-II,

Havličkův Brod 2008-20II, passim. 
w wolnej Czechosłowacji, a obecnie Republice Czeskiej ${ }^{77}$. Prześladowaniom podlegali także między innymi: Vladimir Fořejš z Hostovolic - posiadający 5o-hektarowe gospodarstwo, Jarsolav Piša z Dobrego Pola - właściciel 20-hektarowego gospodarstwa, Ottokar Novak ze Stuparovic - posiadający 22-hektarowe gospodarstwo, Jozef Tejkal ze wsi Nová Ves u Světlé nad Sazavu - gospodarujący na 25-hektarowej zagrodzie, Vaclav Stehlik pochodzący z miejscowości Kněževes - miał 20-hektarowe gospodarstwo. Wszyscy oni byli karani ogromnymi haraczami wynoszącymi od 25 do 50 tys. Kčs. Wszystkich ich więziono, lżono, rabowano, a ich wspaniale rozwijające się ojcowizny niszczono.

Analiza zgromadzonych relacji oraz wynikających z nich danych statystycznych pozwala sformułować wniosek, że wszyscy rolnicy opierający się wstąpieniu do Jednolitych Rolniczych Spółdzielni Produkcyjnych poddawani byli drastycznym represjom finansowym, sięgającym dziesiątek tysięcy koron. $\mathrm{Z}$ powodu braku wpłaty wyznaczonej kwoty niemal natychmiast konfiskowano gospodarstwo. Dokonywano rabunku mienia. Na oczach przerażonych ludzi niszczono mieszkania, profanowano przedmioty kultu religijnego, bito gospodarzy, nie wyłączając osób starych i schorowanych. Straszliwy los spotykał niemal wszystkich bogatszych rolników i ich rodziny na całym terytorium komunistycznej Czechosłowacji. Opisy tego typu brutalnych działań czechosłowackiej służby bezpieczeństwa występowały niemal we wszystkich relacjach.

Zgodnie z polityką władz prześladowano także dzieci rolników, nie zezwalano im na naukę. W sumie represje dotknęły około 7 tys. dzieci i młodzieży, których pozbawiono możliwości nauki w szkołach średnich i na studiach wyższych ${ }^{78}$. Po upadku systemu komunistycznego przestępstwa te nie zostały ukarane ${ }^{79}$.

W okresie nasilonej kolektywizacji wsi dochodziło do masowych wysiedleń rolników czechosłowackich. W powiecie Jindřichůr-Hradeckim wysiedlono siedemdziesiąt rodzin chłopskich, skazując je na poniewierkę,

77 RudolfRehak (Lipany). [Relacja syna i wnuka], [w:] M. Růžička: Vyhnanci I..., s. 259-262; Sesnam, č. 2: Seznam Rodin vystěhovanych zjednolitych krajů, [w:] P. Blažek i in., Akce „K”..., s. 499-5I2; P. Zelenák, Dynamika triedneho boja a úloha dedinských boháćov v procese kolektivizácie na Slovensku, [w:] Formovanie triedy družstevného rolníctva v Československu. Kapitoly z dejin socialistického polnohospodárstva v Československu, Bratislava 1984, s. 267-277; A. Václavů, Ke sporim..., s. 20-23, 45-47.

78 Relacja V. Horejsi (Hostovice),J. Piša (Dobre Pole), O. Novaka (Stipároviče), J. Tejkala (Nova Ves u Suétle nad Sazovou), V. Stehlika (Kneževes), [w:] M. Růžička, Vyhnanci I..., s. 15I-154, 307-309, 32I-323, 326-330, 391-394; K. Jech, Vyloučeni selských dètí ze zemédèlských škol (I95I-I953), [w:] Stránkami soudobých dèjin: sbornik statí k pètašedesátinám historika Karla Kaplana, Praha 1993, s. I23-I4I.

79 P. Fiala, M. Mareš, P. Pšeja, Komunisté a jejich strany, [w:] J. Maliř i in., Politycke strany. Vývojpolitických stran a hnuti v českých zemich Československu, II. díl: Obdobi 1938-2004, Brno 2004, s. I413-I427. 
biedę, a wielu ludzi na śmierć głodową ${ }^{8 \circ}$. Organizatorem tych prześladowań był Vladimir Kodad, funkcjonariusz czechosłowackiego Urzędu Bezpieczeństwa. Drugim takim funkcjonariuszem kierującym zbrodniczymi akcjami w tej części Czech był Karel Vospil, który jako kierujący operatywnym aparatem bezpieczeństwa wraz z podległymi mu czechosłowackimi „ubekami” prześladował tysiące chłopów w tym rejonie kraju ${ }^{8 \mathrm{I}}$.

Chłopi przeciwstawiali się terrorowi aparatu bezpieczeństwa i milicji ludowej. Do aktów oporu doszło do m.in. we wsi Litoboř koło Náchodu w Północnych Czechach. W grudniu i95I r. władze bezpieczeństwa poszukiwały tam „dywersantów” przeciwstawiających się kolektywizacji. Wobec oporu chłopów zastosowano zbiorową odpowiedzialność. Osiemnaście osób skazano na cztery do dwudziestu lat ciężkich więzień. Cztery osoby skazano na śmierć i stracono. Pod wpływem terroru, 28 II 1952 r. mieszkańcy wsi założyli spółdzielnię produkcyjną, tym samym ratując swoje ży$\mathrm{cie}^{8_{2}}$. W Lhotce koło Tasova (powiat Hodonin), gdzie w 1952 r. wysiedlono w brutalny sposób liczne rodziny chłopskie, pozbawiając je majątków, osadzając w ciężkich więzieniach, kopalniach uranu, węgla, kamieniołomach, postawiono pomnik ku czci chłopskich męczenników ${ }^{83}$.

W latach 1957-1958, a więc w okresie "chruszczowowskiej odwilży” komuniści czechosłowaccy, w przeciwieństwie do polskich, dokończyli proces „uspółdzielczania” wsi ${ }^{84}$. W Czechosłowacji zabrano chłopom około 6,I mln ha gruntów, z tego 4,5 mln to grunty orne. W rękach chłopskich zostało około 750 tys. ha, głównie w postaci j działek przyzagrodowych. W końcu lat 50., kiedy w PRL rozwijało się rolnictwo indywidualne, w Czechosłowacji gwałtem kolektywizowano wieś. Na przykład w województwie budziejowickim dwie trzecie spółdzielni produkcyjnych powstało w latach $1957-1958$. W latach $1955-1959 \mathrm{w}$ spółdzielniach znalazło się około 300 tys. ha ziemi (w I955 - 80 tys. ha). Podobną sytuację notowano w Słowacji, gdzie w 1956 r. spółdzielnie obejmowały $38 \%$ ziemi, a w 1957 r. już około $78 \%$. W Słowacji przed całkowitą kolektywizacją wieś chronił górski krajobraz. Jak pisał polski dyplomata, w 1959 r. „sektor socjalistyczny objął 90-95\% użytków rolnych”. Poza kolektywną gospodarką

80 M. C., Sita...

8I L. Svoboda, Perzekuce vesnického obyvatelstva v procesu kolektivizace na Jindrichohradecku, [w:] P. Blažek i in., Akce „K”..., s. 159-164.

82 Zob. Masakrv Litoboři-28XII I95I, [w:] M. Karelová, dz. cyt., s. I64.

83 Pomnik ná silnèvystěhovaným sedlákưm ve Lhotce v Akce „Kulak” (I95I-I954), [w:] tamże, s. 202.

84 V. Březina, Poslední.., s. 69-90; J. Topinka, Dokončení kolektivizace venkova jeho realizace na Berounsku 1957-1962, [w:] Závèrečná fáze..., s. I29-180; K. Kaplan, Kronika komunistikého Československa. Doba tani 1953-1956, Brno 2005, s. 235-375. 
pozostawali robotnicy „posiadający drobne działki ogrodnicze oraz część gospodarstw górskich nie posiadających warunków dla prowadzenia gospodarki zespołowej"s.

\section{Rola aparatu partii komunistycznej w kolektywizacji wsi czechosłowackiej}

W Czechosłowacji doszło do tak daleko sięgającej kolektywizacji, ponieważ była tam niezwykle silna partia komunistyczna. Jej przywódcy byli zdeterminowani, aby rolnictwo skolektywizować i upodobnić kraj do radzieckiego modelu gospodarczego. Według polskich obserwatorów życia gospodarczego Czechosłowacji czynnikami, które zadecydowały „o sukcesie” w zakresie socjalistycznego przeobrażenia wsi w tym kraju, były: a) praca polityczna, rola partii w kierowaniu walką o przebudowę wsi, b) znaczna pomoc klasy robotniczej, c) polityka klasowa państwa, d) pomoc materialna udzielona spółdzielniom produkcyjnym, e) skierowanie na wieś poważnej ilości kadr politycznych i specjalistów rolnictwa" ${ }^{" 86}$. KPCz mając silne wpływy wśród ludności pozarolniczej i byłych robotników rolnych, cel ten mogła zrealizować.

Wśród 323 tys. członków działających w partii na wsi jedynie 98 tys. było członkami rolniczych spółdzielni produkcyjnych. Pozostali byli pracownikami aparatu administracyjnego, oświatowego, przemysłu terenowego, spółdzielczości, banków. W I,4 tys. wsiach czechosłowackich, w istniejących tam spółdzielniach nie było członków partii. W około tysiącu wsi do partii należało po jednym członku spółdzielni, w kolejnym tysiącu spółdzielni do partii należało po dwóch członków spółdzielni. Natomiast organizacje partyjne i grupy komunistyczne obejmowały swym zasięgiem prawie całą wieś czechosłowacką. W tych wsiach, gdzie liczba chłopów członków partii była stosunkowo mała, w skład grup partyjnych wchodzili mieszkający na wsi robotnicy ${ }^{87}$. Obok organizacji partyjnej na samej wsi znaczną rolę w budowaniu spółdzielni produkcyjnych odegrały kierowane tam ekipy „aktywu”. W 1957 r. W województwie budziejowickim na wieś skierowano brygady agitacyjne w liczbie siedmiuset ludzi na okres pięciu zimowych miesięcy. Grupy te terroryzowały wieś, przymuszając mieszkańców, aby wstępowali

85 AMSZ, DI.WCz, Czechosłowacja 232, t. 450, wiązka 49, s. 29I, Notatka z pobytu w ČSR ... lipiec I960 r.; W. Misiuna, dz. cyt., s. 175-I85; I. Rubik, dz. cyt., s. 27-28, 24-37, 51-57.

86 AMSZ, DI.WCz, Czechosłowacja, t. 450, wiązka 49, s. 292, Notatka z pobytu w ČsR ... lipiec I960 r.; V. Průcha, Vývojzemédèlské výrobyv Československu vobdobisocializace vesnice, [w:] Osudy zemédělského..., s. 3I-33; J. Pešek, Reorganizácia..., s. 37I-395.

87 AMSZ, DI.WCz, Czechosłowacja 232, t. 450, wiązka 49, s. 292, Notatka z pobytu w ČsR ... lipiec I960 r.; L. Budinský, Trinást'prezidentov, Bratislava 2004, s. 16I-165, 176-185; S. Balik, J. Holzer, J. Šedo, Komunistická strana Československa, [w:] Politycke..., s. 1243-1249. 
do spółdzielni produkcyjnych ${ }^{88}$. Dużą rolę w walce o umocnienie i rozwój spółdzielni produkcyjnych odegrało skierowanie na wieś licznych kadr partyjnych i specjalistów rolnictwa. W wyniku dokonanej reorganizacji administracyjnej, a w szczególności zmniejszenia liczby powiatów (z trzystu do stu), nad kolektywizacją rozciągnięto szczelniej nadzór. Powiększono liczbę aktywistów na wsi. W latach 1957-1959 skierowano do gromadzkich rad narodowych i spółdzielni produkcyjnych in tys. komunistów, młodych zindoktrynowanych, dobrze opłaconych, którzy z dobrym efektem kolektywizowali wieś czechosłowackąa

„Kierownikami” akcji uspółdzielczania byli sekretarze Gminnych Rad Narodowych, komuniści „stosunkowo wysoko uposażeni”, zarabiający około 2-3 tys. Kčs miesięcznie, co kilkakrotnie przewyższało zarobki spółdzielców. Dostawali oni dodatkowe apanaże, co motywowało ich do gorliwego kolektywizowania wsi ${ }^{\circ}$. Komitety Powiatowe $\mathrm{KPCz}$ wraz z radami narodowymi wydawały specjalne odezwy do chłopów. Grupy agitacyjne odwiedzały chłopów w ich mieszkaniach i przekonywały do spółdzielczości produkcyjnej. Zgodnie z poleceniem władz powiatowe komitety partii komunistycznej redagowały gazetki ścienne i rozprowadzały je po wsiach. W gazetkach tych informowano o wynikach gospodarowania i wzorcowych metodach pracy spółdzielców na terenie ich działania. Działalność taką prowadził m.in. Komitet Powiatowy KPCz w Jindřichův Hradec. Komitet ten w wydawanych

88 AMSZ, DI.WCz, Czechosłowacja 232, t 450, wiązka 49, s. 292, Notatka z pobytu w ČsR ... lipiec 1960 r.; Masakrv Litoboři...; V. Forst, dz. cyt., s. 292-296; Déjiny Komunistické Strany Československa, Praha 196I, s. I00-I20; S. Balik, J. Holzer, J Šedo, Komunistická strana..., s. 1243-1247, I25I-I255; Př́hled dèjin KSČ, Praha 1978, s. 350-372; K. Kaplan, Kádrová nomenklatura KSČ 1948-1958. Sbornik dokumentů, Praha 1992, s. 75-86; tenże, Aparát ÚV KSČ́ v letech 1948-1956, Praha 1993, s. 53-72.

89 AMSz, DI.WCz, Czechosłowacja 232, t. 450, wiązka 49, s. 292-293, Notatka z pobytu w ČsR ... lipiec 1960 r.; L. Svoboda, dz. cyt., s. 158-164, 176-190; V. Hlavová, dz. cyt., s. 172-179; S. Cambel, V. Skrip, A. Vanko, Rolnicka politika KSČ vobdobi výstavby socializmu na Slovensku, Bratislava 1978 , s. 64-74. Autorzy publikacji wydawanych w czasach komunistycznych afirmatywnie pisali o zaangażowaniu komunistów lokalnych w kolektywizację wsi, np.: V. V. Marjina, G. P. Murašková, Rozorané $m e d z e$, Bratislava 1971, s. 164-175. Autorzy tej książki pokazali mimowolny dramat niszczenia wsi i udział w tym procesie komunistów w tych latach. Dopiero po 1989 roku pokazano prawdziwy dramat czechosłowackich rolników w dziele M. Růžički, Vyhnanci... W opublikowanych tam 205 relacjach z 205 wsi, głównie z terenu Czech, pokazano zbrodniczą rolę KPCz w tym procesie.

90 AMSZ, DI.WCz, Czechosłowacja 232, t. 450, wiązka 49, s. 294, Notatka z pobytu w ČSR ... lipiec 1960 r.; P. Hájek, Jdepevněku předu naše zem. Krajina českých zemív obdobi socialismu 1948-1989, Praha 2008, s. 13-50. W pracy tej pokazano skalę spustoszeń jakich dokonali komuniści na wsi czechosłowackiej w latach 1948-1989. Zniszczyli oni wielkoobszarowe gospodarstwa chłopskie, zrabowali ziemie, które wcielili do JZD lub PGR. Doprowadzili do ruiny zabudowania chłopskie lub je zniszczyli. W procesie tym brali udział aktywiści partyjni od szczebla lokalnego aż po KC KPCz. W założeniach programowych tej partii znalazły się zapisy dotyczące zniszczenia indywidualnego rolnictwa chłopskiego. Wyraz tego dawali liczni przedstawiciele tej partii. Zob.: Smernice..., s. 373-400; Rozvojem hospodařeni JZD. K rozhodnemu obratu v zemédelske wyrobe. Z projevu ministra zemédelstvi a lesniho hospodaŕstvi soudruha Lubomira Strougala, „Rude Pravo”, 20 III 1959, nr 70. 
gazetkach informował spółdzielców o osiągnięciach miejscowych spółdzielni rolniczych i ich zadaniach $w$ rozwoju produkcji rolnej. Na polecenie władz centralnych $\mathrm{KPCz}$ wydawał on również „bogato ilustrowane broszury o nowych technologiach hodowli trzody chlewnej". W oparciu o te publikacje w rolniczych spółdzielniach produkcyjnych prowadzono szkolenia z zakresu „karmienia metodami suchej paszy trzody chlewnej”. Na wzór sowiecki drukowano także „broszury zwierające rysunki i karykatury do kopiowania gazetek ściennych, w których w niewybredny sposób” obrazowano życie bogatych chłopów czechosłowackich wrogów socjalizmu" ${ }^{9}$. W Komitecie Powiatowym KPCz w Hradcu Kralove zatrudniono sześciu pracowników ze średnim wykształceniem i roczną szkołą partyjną, jednego inżyniera, czterech pracowników z Wyższą Szkołą Partyjną, jednego pracownika z czteroletnią Szkołą Partyjną. Cała ta grupa z „wielkim oddaniem” agitowała za spółdzielczością, brała udział w przekonywaniu okolicznych chłopów do gospodarowania w rolniczych spółdzielniach produkcyjnych ${ }^{92}$.

W komunistycznej Czechosłowacji duże znaczenie w rozwoju spółdzielczości produkcyjnej miał system ulg i pomocy materialnej, których państwo udzielało spółdzielniom. Wsparcie to obejmowało:

a) przy istniejącym systemie progresji obowiązującej w podatku gruntowym spółdzielni miały normę odpowiadającą gospodarstwu o areale $3^{1 / 2}-5$ ha; b) przy zagospodarowaniu przejętych gruntów zwolnienia od obowiązkowych dostaw w ciągu $2^{1 / 2}$ lat [wolnizna]; c) przydzielenie na korzystnych warunkach paszy za ponadplanowe dostawy; d) większe przydziały i niższe ceny nawozów sztucznych; e) niższe opłaty za usługi POM [poniżej kosztów własnych]; f) pomoc przy budowie inwentarskich polegająca na udzielaniu kredytów, dotacji do 30\% wartości budynku oraz coroczne umarzanie $5 \%$ zaciągniętego kredytu. Ogólem dawało to do $80 \%$ udziału państwa, a średnio dla całego budownictwa inwentarskiego wynosiło 50\%. Na budownictwo w spółdzielniach szła największa część pomocy państwowej³.

9I AMSz, DI.WCz, Czechosłowacja 232, t. 450, wiązka 49, s. 294-295, Notatka z pobytu w ČSR ... lipiec 1960 r.; L. Svoboda, dz. cyt., s. I55-158, I64-176, 182-189; Š. Rokosová, dz. cyt., s. I59-163.

92 AMSz, DI.WCz, Czechosłowacja 232, t. 450, wiązka 49, s. 295, Notatka z pobytu w ČsR ... lipiec 1960 r.; L. Svoboda, dz. cyt., s. 168-190; J. Pešek, Přerod jihočeské vesnice. K historii združstevñování zemédělstvi Českobudějovického kraje v letech I949-1959, České Budejoviče 1985, s. 49-58.

93 AMSz, DI.WCz, Czechosłowacja 232, t. 450, wiązka 49, s. 295-296, Notatka z pobytu w ČsR ... lipiec 1960 r.; L. Feierabend, dz. cyt., s. 66-76; W. Misiuna, dz. cyt., s. 163-174. 
Przed wprowadzeniem jednolitych cen na produkty rolne, do i I 1960 r., pomoc państwa dla spółdzielni produkcyjnych sięgała kwoty 4 mld Kčs. W 1960 r. pomoc ta obejmowała w zasadzie tylko budownictwo i meliorację. Wynosiła rocznie około mld Kčs. Wszyscy spółdzielcy byli ubezpieczeni i otrzymywali różnego rodzaju dodatki rodzinne ${ }^{94}$.

Na początku lat 60 . XX w., po całkowitym uspółdzielczeniu wsi, statuty spółdzielni produkcyjnych ostatecznie przewidywały prawo posiadania działki przyzagrodowej do wysokości o,5 ha (z tego I/5 mogła mieć charakter intensywny, np. uprawę winnic i sadów) oraz utrzymanie jednej krowy i dwóch świń ${ }^{95}$. Nastąpił ponownie gwałtowny odpływ ludności rolniczej ze wsi do miast, do pracy w przemyśle. Stan zatrudnienia w rolnictwie zmniejszył się blisko o połowę. Nastąpiło zwiększenie wydajności pracy, ale to nie rekompensowało powstałych ubytków. $\mathrm{Na}$ wsi brakowało ludzi do pracy. W latach 60. części spółdzielców zabrano działki przyzagrodowe po to, aby pracowali na gruntach spóldzielczych, a nie na własnych minipoletkach ${ }^{96}$. Władze podjęły decyzje o ograniczeniu upraw na przyzagrodowych działkach rolnych. Starano się systematycznie zmniejszyć hodowlę krów, nakazywano oddawać je do spółdzielni. Na przykład w województwie brneniskim spółdzielców zmuszano do likwidowania własnej hodowli krów. Rolnicy-hodowcy mleko musieli kupować w spółdzielni za opłatą. Przydziały powiązano $\mathrm{z}$ wypracowaniem odpowiedniej ilości dniówek ${ }^{97}$. W ten sposób chłopów czechosłowackich zamieniono ostatecznie w najemnych robotników

94 AMSZ, DI.WCz, Czechosłowacja 232, t. 450, wiązka 49, s. 297, Notatka z pobytu w ČSR ... lipiec I960 r.; J. Pernes, Závérečná etapa..., s. 38-52; I. Rubik, dz. cyt., s. 57-59, 15I-155, 170-I97.

95 AMSZ, DI.WCz, Czechosłowacja 232, t. 450, wiązka 49, s. 297, Notatka z pobytu w ČSR ... lipiec 1960 r.; B. Robeš, Holubice za léta totalitní 1948-1989, [w:] Závěrečná fáze..., s. 198-224; B. Strużek, dz. cyt., s. 54-56, 66-68.

96 AMSz, DI.WCz, Czechosłowacja 232, t. 450, wiązka 49, s. 297, Notatka z pobytu w ČSR ... lipiec I960 r.; W. Misiuna, dz. cyt., s. I99-205; D. Choma, Dwadzieścia lat socjalistycznego rozwoju rolnictwa w Czechostowacji, „Wieś Współczesna” 1970, nr II, s. 52-55; A. Drda, Konec vesnických upiri. O kolektivizaci, kulacich a likvidaci venkova. A takéo panu Stýblovi, posledním obywateli Rajdlova statku,[w:] Kolektivizace venkova..., s. 282-293.

97 AMSZ, DI.WCz, Czechosłowacja 232, t. 450, wiązka 49, s. 298, Notatka z pobytu w ČSR ... lipiec 1960 r.; A. Kita, W. Jurek, A. Niedźwiedzki, dz. cyt., s. 44-46. W 1953 roku zmieniono statuty JZD. Autorzy tego opracowania pisali, że w Czechosłowacji „Nowe wzorcowe statuty przewidywały, że członkowie jednolitych spółdzielni produkcyjnych łączą wszystkie swoje grunty, zaorywują dzielące je miedze i w ten sposób tworzą się wielkie, scalone pola uprawiane wspólnie przez spółdzielców - z tym, że wniesiona do spółdzielni ziemia stanowi nadal własność członków spółdzielni. Rodzina członka spółdzielni, który wkład, ma prawo pozostawić do swego własnego użytku działkę przyzagrodową wielkości do o,5 ha, a w rejonach upraw pastewnych działka ta może być na podstawie uchwały powiatowej rady narodowej powiększona do i ha. Z każdym nowo wstępującym członkiem spisuje się akt o wniesionej przez niego do spółdzielni ziemi”. 
rolnych $^{98}$. Na początku lat $60 . \mathrm{XX}^{\mathrm{x}}$ w. polscy obserwatorzy stwierdzili, że w Czechosłowacji władze komunistyczne tego państwa poszły „odmienną drogą" niż w Rumunii, na Węgrzech czy nawet NRD i Bułgarii. W krajach tych zezwolono na rozwój działek przyzagrodowych. Nawet w Związku Radzieckim polityka ograniczenia hodowli na przyzagrodowych działkach była możliwa99. Działania czechosłowackich władz komunistycznych spowodowały gwałtowne zubożenie wsi. W obronie przed tak brutalną polityką czechosłowackich komunistów nastąpiła ucieczka ludności do miast ${ }^{100}$.

\section{Bibliografia}

\section{Źródła archiwalne}

Archiwum Ministerstwa Spraw Zagranicznych, Departament I. Wydział Czechosłowacki

\section{Źródła drukowane}

Blažek P. i in., Akce „K”. Vyhnáni sedláku a jejich rodin z usedlostív padesátých letech. Studie, seznamy a dokumenty, Praha 2010.

Blažek P., Kubálek M., Akce „Kulak”. Přijetí, uplaňowáni a zršeni smérnice tři ministrü,

[w:] P. Blažek i in., Akce „K”. Vyhnáni sedláki a jejich rodin z usedlostív padesátých letech. Studie, seznamy a dokumenty, Praha 2010.

„Jutro Polski” 1949, 1952, 1954, 1959, 1962

Kaplan K., Kádrová nomenklatura KSČ 1948 -1958. Sborník dokumentů, Praha 1992.

OdX. do XI. Sjezdu KSČ. Usneseni a dokumenty UV KSČ, Praha 1958.

Potlačená zprăva. Zprăva komise ÚV KSČ o politických procesech a rehabilitacich v československu (1949-1968), úvod a doslov J. Pelikán, Vien 1970.

„Rude Pravo” I959

Růžička M., Vyhnanci I. Akce „Kulak”, zločin proti lidskosti, Harličkův Brod 2008.

Růžička M., Vyhnanci II. Akce „Kulak”, zločin proti lidskosti, Havličkův Brod 201 I.

Statistická ročenka ČSSR Ig60, Praha 1960.

Statistická ročenka ČSSR I970, Praha 1970.

Vyhnanci. Akce „Kulak”, zločin proti lidskosti, zebrał M. Růžička, Praha 2008-20II.

"Wieś Współczesna” 1970

„Zemědělská Ekonomika” 1961, 1969

98 AMSz, DI.WCz, Czechosłowacja 232, t. 450, wiązka 49, s. 298-299, Notatka z pobytu w ČsR ... lipiec 1960 r.; J. Urban, Kolektivizace venkova v Horním Polabi. Od Fenoménů k aktérům a jejich motivacim, Praha 2016, s. 65-148; tenże, Venkov..., s. 199-236, 243-26r; K. Strapocová, Proces

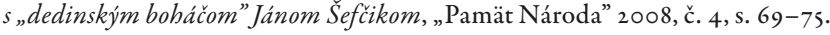

99 AMSz, DI.WCz, Czechosłowacja 232, t. 450, wiązka 49, s. 298-299, Notatka z pobytu w ČsR ... lipiec 1960 r.; J. Urban, Venkov..., s. 59-125; P. Novák, Výkonnost československého zemèdèlství v mezinárodnim srovnáni v so. letech 20. století, [w:] Kolektivizace venkova..., s. 136-155.

100 AMSZ, DI.WCz, Czechosłowacja 232, t. 450, wiązka 49, s. 299-300, Notatka z pobytu w ČSR ... lipiec 1960 r.; W. Misiuna, dz. cyt., s. 208-211; B. Strużek, dz. cyt., s. 60-62, 65-68; J. Rychlík, Kolektivizace vestředni a wýchodni Evropè, [w:] Kolektivizace venkova..., s. 13-30; N. Swain, Typlogie východoevropských podob kolektivizace, [w:] Kolektivizace venkova..., s. 30-59. 


\section{Literatura}

Agenti Zelené internacionály. Nepràtelé naši vesnice, Praha 1952.

Balik S., Holzer J., Šedo J., Komunistická strana Československa, [w:] J. Malî́ i in., Politycke strany. Vývoj politických stran a hnutiv vèských zemich Československu, II. díl: Obdobi I938-2004, Brno 2004.

Barnovský M., Prestávka medzi prvou a druhou etapou kolektivizáacie, [w:] Osudy zemédélského družstvenictvi ve 2o. století. Sbornik príspevkuiz mezinárodni konference konané ve dnech Is-I6 kvètna 2002. Vènovaný Lubomíru Slezákovi k. 70. narozeninám, „Studie Slovackeho Muzea" 2002, č. 7.

Blažek P., Kubálek M., „Chtěl jsem mit svobodné zemédělce ve svobodné zemi”. Sedlák a politik Stanislav Broj, [w:] Kolektivizace venkova v Československu 1948-196o a středoevropské souvislosti, red. P. Blažek, M. Kubálek, Praha 2008.

Bouvier Ch., La collectivisation de l'agriculture. U.R.S.S., Chine, Démocraties populaires, Warszawa 1958.

Březina V., Kolektivizace zémédèlstvív Československu v letech I9s5-I96o, [w:] Kolektivizace venkova v Československu 1948-1960 a středoevropské souvislosti, red. P. Blažek, M. Kubálek, Praha 2008.

Březina V., Posledni fáze kolektivizace na středni a severni Moravě, [w:] Závèrečná fáze kolektivizace zemédělstvi v Československu 1957-1960. Sbornik přispěvkü, red. V. Březina, J. Pernes, Brno 2009.

Březina V., Přlohy, [w:] Závèrečná fáze kolektivizace zemédèlstvív Československu 1957-1960. Sbornik prispèvekio, red. V. Březina, J. Pernes, Brno 2009.

Budinský L., Trinást'prezidentov, Bratislava 2004.

Burešová J., Kolektivizace jako destrukčni proces v životé venkova, [w:] Kolektivizace venkova v Československu 1948-1960 a středoevropské souvislosti, red. P. Blažek, M. Kubálek, Praha 2008.

Burešová J., Politický a institucionální rámec kolektivizace zemédèlstvív Československu se zamèrenim na historická východiska, [w:] P. Blažek i in., Akce „K”. Vyhnáni sedlákủ a jejich rodin z usedlosti v padesátých letech. Studie, seznamy a dokumenty, Praha 2010.

Burešová J., Zemédělská politika v Československu v letech I948-1960 jako součást vývoje komunistických režimũ v Evropě, „Sborník Prací Moravských Historiků” 1996, č. 21: Studijni materiály výzkumnébo projektu Československo 1945-1967.

Burešová J., Zemédèlstvív Českých zemích a na Slovensku vpodminkách „kolektivizace” 1949-Ig6o. (Poznámky k prevratu v životě a práci zemédëlcü), „Česko-Slovenská Historická Ročenka" 1998, [Brno].

Cabada L., Šanc D., Českýs stranický systém ve 20. stoleti, Plzeň 2005.

Cambel S., Pät'desiate roky na slovenskej dedine. Najt'ažšsie roky kolektivizácie, Peršov 2005.

Cambel S., Skrip V., Vanko A., Rolnicka politika KSČ v obdobi výstavby socializmu na Slovensku, Bratislava 1978.

Chyba A. i in., Vývoj Československé ekonomiky a hospodárská politika KSČ. Studijni materiály, Praha 1971.

Déjiny Komunistické Strany Československa, Praha 1961.

Deset let JZD, Praha 1959.

Dostál V. V., Agrárni strana. Její rozmach a zánik, Brno 1998.

Drda A., Konec vesnických upiru. O kolektivizaci, kulacich a likvidaci venkova. A takéo panu Stýblovi, poslednim obywateli Rajdlova statku, [w:] Kolektivizace venkova v Československu 1948-1960 a středoevropské souvislosti, red. P. Blažek, M. Kubálek, Praha 2008.

Feierabend L., Zemédělské družstevnictví v Československu do roku, Černa v Pošumavi 2007.

Fiala P., Mareš M., Pšeja P., Komunisté a jejich strany, [w:] J. Malií i in., Politycke strany. Vývoj politických stran a hnuti v českých zemích Československu, II. díl: Obdobi I938-2004, Brno 2004.

Forst V., Czechostowacja, tłum. i oprac. wersji polskiej M. Kamieniecki, Warszawa 1966.

HájekP.,Jdepevněkupredunašezem.Krajinačeskýchzemívobdobisocialismu1948-1989, Praha2008. 
ROMUALD TURKowsKı Następstwa społeczno-gospodarcze kolektywizacji wsi czechosłowackiej...

Historia gospodarcza Czechostowacji XX wieku, pod red. V. Průchy, Warszawa 1979.

Hlavová V., Policajno-administrativny a ekonomický nátlak na rolnikom počas I. etapy kolektivizácie, [w:] Od diktatúry k diktaturre. Slovensko v rokoch 1945-1953, red. M. Barnovský, Bratislava 1995.

Jech K., Soumrak selského stavu 1945-1960, Praha 200 I.

Jech K., Vyloučeni selských dètíze zemédèlských škol (IgsI-I9s3), [w:] Stránkami soudobých déjin. Sbornik statík pètašedesátinám historika Karla Kaplana, Praha 1993.

Kaplan K., Aparát ÚV KSČ v letech 1948-1956, Praha 1993.

Kaplan K., Ceskoslovensko v letech $1945-1948$, cz. I, Praha 1991.

Kaplan K., Ceskoslovensko v letech I948-1953, cz. 2: Zakladatelské obdobi komunistického režimu, Praha 1992.

Kaplan K., Kronika komunistikého Československa. Doba tani 1953-1956, Brno 2005.

Kaplan K., Paleček P., Komunistický rězim a politické procesy v Československu, Brno $200 \mathrm{I}$.

Karelová M., Tajemná mista komunismu. Fascinujici mista české historie, Brno 2017.

Kazimour J., Hospodárský vývoj Československa, Praha 1980.

Kita A., Jurek W., Niedźwiedzki A., Spótdzielczość produkcyjna w świetle ustawodawstwa i doświadczeń, Warszawa 1956.

Kvapilová I., Organizačni vývoj SNB v so. letech se zaměrenim na jeho veřejnè bezpečnostni složku, „Sborník Achivu Ministerstva Vnitra” 2004, nr 2.

Marjina V. V., Murašková G. P., Rozorané medze, Bratislava 1971.

Matejka J., Gottwald, Praha i97.

Misiuna W., Przemiany w rolnictwie Czechostowacji. Od uwtaszczenia do uspótdzielczenia gospodarki chtopskiej, Warszawa 1972.

Národni hospodárstvív ČSR v letech 1945-1960, Praha 1960.

Novák P., Výkonnost československého zemédèlstvi v mezinárodnim srovnáni v so. letech 20. stoleti, [w:] Kolektivizace venkova v Československu 1948-1960 a středoevropské souvislosti, red. P. Blažek, M. Kubálek, Praha 2008.

Pernes J., Snahy o prekonáni politicko-hospodárské krize v Československu v roce I953, Brno 2000.

Pernes J., Závèrečná etapa kolektivizace zemédèlstvi v Československu 1957-Ig6o, [w:] Závèrečná fáze kolektivizace zemédèlstvi v Československu 1957-196o. Sbornik přispěvekiu, red. V. Březina, J. Pernes, Brno 2009.

Pešek J., Obrat ve združstevňováni československého zemédělstvi v letech 1957-1958, „Československý Časopis Historický” 1986, č. 4.

Pešek J., Přerod jihočeské vesnice. K historii združstevñováni zemédèlstvi Českobudějovického kraje v letech 1949-1959, České Budejoviče 1985.

Pešek J., Reorganizácia strojových a traktorových stanic v Československu v rokoch 1959-1969, „Historičky Časopis” 1985 , č. 3.

Poniatowski J., Uwagi o ustroju rolnym, [w:] Dylematy gospodarki polskiej, red. W. Czerwiński, Londyn 1965.

Průcha V., Vývoj zemédélské výroby v Československu v obdobi socializace vesnice, [w:] Osudy zemédèlskébo družstvenictvi ve 2o. století. Sbornik príspevkü z mezinárodnikonference konané ve dnech is-I6 května 2002. Vènovaný Lubomiru Slezákovi k. 70. narozeninám, "Studie Slovackeho Muzea" 2002, č. 7.

Přebled dèjin KSČ, Praha 1978.

Renner H., Samson I., Dejiny Československa po roku 1945, Bratislava 1993.

Robeš B., Holubice za léta totalitni 1948-1989, [w:] Závérečná fáze kolektivizace zemédèlství $v$ Československu 1957-1960. Sbornik prispèvkiu, red. V. Březina, J. Pernes, Brno 2009.

Rokoský J., Jan Malypetr. Prvorepublikový premiér a Národni soud v roce 1947 (I čast), "Středni Europa” 1998, č. 82.

Rokoský J., Jan Malypetr. Prvorepublikový premiér a Národni soudv voce 1947 (II čast), "Středni Europa" 1998, č. 83.

Rokoský J., Josef Černý, okupace, kolaborace (II čast), „Středni Evropa” 1997, č 72-73. 
ROMUALD TURKowsKı Następstwa społeczno-gospodarcze kolektywizacji wsi czechosłowackiej...

Rokoský J., Rudolf Beran a jeho doba. Vzestup a pád agrárni strany, Praha 2011.

Rokoský J., Svobodný sedlák na svobodnépiodè. Osud agrárni strany v Československu po druhésvétové válce, [w:] Kolektivizace venkova v Československu $1948-1960$ a středoevropskésouvislosti, red. P. Blažek, M. Kubálek, Praha 2008.

Rokosová Š., Administrativní opatřeni - jedna z forem perzekuce sedlákủ komunistickým režimem, „Securitas Imperii” 2003, č. I0, [Praha].

Rozvoj československého zemédèlstvív letech 1966-1970, Praha 1970.

Rozwój gospodarki krajów Rady Wzajemnej Pomocy Gospodarczej w latach 1950-1968, Warszawa 1969.

Rubik I., Rolnictwo w Czechostowacji, Warszawa 1966.

Ruml V., „Vesnický boháč Jan Ruml (I8go-I95I), [w:] Kolektivizace venkova v Československu I948-1960 a středoevropské souvislosti, red. P. Blažek, M. Kubálek, Praha 2008.

Rychlík J., Collectivization in Czechoslovakia in Comparative Perspective, 1949-1960, [w:] The Collectivization of Agriculture in Communist Eastern Europe. Comparison and Entanglements, red. C. Iordachi, A. Bauerkämper, Budapešt-New York 2014.

Rychlík J., Kolektivizace vestředni a wýchodni Evropè, [w:] Kolektivizace venkova v Československu $1948-1960$ a středoevropské souvislosti, red. P. Blažek, M. Kubálek, Praha 2008.

Sikora S., Reakcia obyvatelstva na politické procesy $v$ Česko-Slovensku začiatkom pätdesiatych rokov, [w:] Od diktaturry k diktatúre. Slovensko v rokoch 1945-1953, red. M. Barnovský, Bratislava 1995 .

Strapocová K., Proces s „dedinským boháčom” Jánom Šefčikom, „Pamät Národa” 2008, č. 4.

Strużek B., Rolnictwo europejskich krajów socjalistycznych. Problemy spoteczno-ekonomiczne, Warszawa 1963.

Surosz M., Pepiki. Dramatyczne stulecie Czechów, Warszawa 2010.

Svoboda L., Perzekuce vesnického obyvatelstva v procesu kolektivizace na Jindrichohradecku, [w:] P. Blažek i in., Akce „K”. Vyhnáni sedlákì a jejich rodin z usedlostí v padesátých letech. Studie, seznamy a dokumenty, Praha 2010.

Swain N., Typlogie východoevropských podob kolektivizace, [w:] Kolektivizace venkova $v$ Československu $1948-1960$ a stredoevropskésouvislosti, red. P. Blažek, M. Kubálek, Praha 2008.

Szymczak T., Organy wtadzy i administracji europejskich państw socjalistycznych, Warszawa 1970.

Tomaszewski J., Czechostowacka Republika Socjalistyczna, [w:] Dzieje państw socjalistycznych. Gospodarka, spoteczeństwo, polityka, pod red. J. Ciepielewskiego, Warszawa 1986.

Topinka J., Dokončeni kolektivizace venkova jeho realizace na Berounsku 1957-1962, [w:] Závèrečná fáze kolektivizace zemédèlstvív Československu 1957-Ig6o. Sbornik přispěvkĭ, red. V. Březina, J. Pernes, Brno 2009.

Urban J., Kolektivizace venkova v Hornim Polabi. Od Fenoménů k aktérüm a jejich motivacim, Praha 2016.

Urban J., Venkov pod kolektivizačni knutou. Okolnosti exemplárního „kulackého” procesu, Praha $20 \mathrm{Io.}$

Václavů A., Ke sporưm o zemédèlské družestevnictvi a kolektivizaci v Českolovensku, „Studie z Hospodářských Dějin" 1998 , č io.

Václavů A., O agrárni otázce v socialistickém hnutí, „Revue Dějin Socialismu” 1968, č. I.

Vodička K., Cabada L., Politický systém České republiky. Historie a soucasnost, Praha 2003.

Vomela M., Kolektivizace v Československu a její politické motivy, [w:] Kolektivizace venkova v Československu 1948-1960 a středoevropské souvislosti, red. P. Blažek, M. Kubálek, Praha 2008.

Žaček P., Nástin rozpracováni „problematiky agrárnici” Státni bezpečnostív padesátých a šedesátých letech 2o. století, [w:] Küloze a významu agrárního hnutiv českých a československých dèjinách, Praha $200 \mathrm{I}$.

Závèrečná fáze kolektivizace zemédělstvi v Československu 1957-1960. Sbornik přispèvkư, red. V. Březina, J. Pernes, Brno 2009.

Zelenák P., Dynamika triedneho boja a úloha dedinských bohácovv v procese kolektivizácie na Slovensku, [w:] Formovanie triedy družstevného rolnictva v Ceskoslovensku. Kapitoly $z$ dejin socialistického polnohospodárstva v Československu, Bratislava 1984. 
Streszczenie: Artykuł dotyczy brutalnej, wzorowanej na stalinowskim modelu, kolektywizacji wsi czechosłowackiej. Oparty został o polskie świadectwa dokumentowe zaczerpnięte z polskich archiwów głównie wytworzonych przez służby dyplomatyczne państwa komunistycznego w latach 1945-1960/196I. W artykule pokazano kulisy forsownej kolektywizacji, której efektem było zniszczenie znakomicie prosperującego rolnictwa czechosłowackiego. Konsekwencją działań reżymu komunistycznego było zainstalowanie na wsi czechosłowackiej, obcej kulturze tego narodu, sowieckiego modelu gospodarowania, etosu komunistycznego.

Słowa klucze: wieś czechosłowacka, terror, prześladowania, Rudolf Beran, obozy pracy, zniszczenie indywidualnych gospodarstw chłopskich

Summary: The article concerns the brutal collectivization of the Czechoslovak village, modeled on the Stalinist model. It was based on Polish documentary certificates taken from Polish archives mainly created by the diplomatic services of the communist state in 1945-1960/196r. The article shows the backstage of strenuous collectivization, which resulted in the destruction of thriving Czechoslovak farming. The consequence of the communist regime's activities was the installation in the Czechoslovak village of the Soviet culture of the soviet nation, the communist ethos.

Keywords: Czechoslovak village, terror, persecution, Rudolf Beran, labor camps, the destruction of private farms 